\title{
Financial Crisis in East Asia: Bank Runs, Asset Bubbles and Antidotes
}

Marcus Miller and Pongsak Luangaram

CSGR Working Paper No. 11/98

July 1998
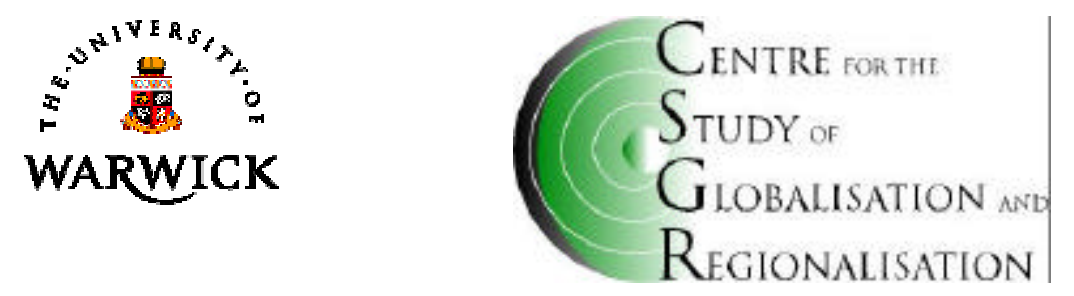

E.S.R.C
ECONOMIC
\& SOCIAL
RESEARCH
COUNCIL

Centre for the Study of Globalisation and Regionalisation (CSGR), University of Warwick, Coventry CV4 7AL, United-Kingdom. URL: http://www.warwick.ac.uk/fac/soc/CSGR 


\title{
Financial Crisis in East Asia: Bank Runs, Asset Bubbles and Antidotes
}

Marcus Miller and Pongsak Luangaram ${ }^{1}$

University of Warwick, Department of Economics and CSGR

CSGR Working Paper No. 11/98

July 1998

\begin{abstract}
:
Was the East Asian crisis just a creditor panic with a mad scramble for liquidity that brought the banking system to its knees and the region's much-vaunted 'economic miracle' to a standstill? Or was the miracle indeed flawed by fundamental problems in asset prices and resource allocation? After a summary of the facts and an outline of various types of financial crisis, we conclude that the truth involves both factors, interacting in a vicious downward spiral. There certainly was panic among the creditors but it was triggered by genuine problems of overinvestment and overvaluation in emerging East Asian economies.

Before turning to outline various approaches of crisis prevention and management and a brief account of the future prospects, we discuss how contagion can occur in environments where investors are poorly informed and each looks to the others for guidance. The paper ends with immediate steps that might help resolve the current crises; and with proposed reforms to the international monetary system to prevent a recurrence.
\end{abstract}

Keywords:. East Asian crisis; Creditor panic; Asset bubbles; Moral hazard; Contagion; Crisis resolution; Reform of the international monetary system.

Address for correspondence:

Marcus Miller

Department of Economics

University of Warwick

Coventry CV4 7AL, U.K.

Tel: (44 1203) 523049

Fax: (44 1203) 523032

Email: marcus.miller@warwick.ac.uk

\footnotetext{
${ }^{1}$ Acknowledgments: This paper has benefited substantially from suggestions made by the Clare Group and discussions with Luisa Corrado and Lei Zhang of Warwick University. Financial support from the ESRC, under project No L120251024 "A bankruptcy code for sovereign borrowers" is gratefully acknowledged. This paper draws on joint work with Hali Edison of the Federal Reserve Board and with T. J. Bond of the IMF but the views expressed here are solely the responsibility of the current authors, and should not be interpreted as reflecting those of the Board of Governors of the Federal Reserve System, nor of the IMF and its Executive Board.
} 


\section{Non-Technical Summary:}

No one can deny the outstanding success of the East Asian economies in the last two decades of rapid economic growth backed by surging capital inflows. Key questions posed by the current crisis are: what went wrong, and why? how to fix it? and, how to prevent a recurrence? To answer them, the paper begins with a brief overview of recent developments in the miracle economies of East Asia, focusing mainly on Korea, Indonesia and Thailand. We focus too on some of the shadows that came to darken the glittering success story - on declining competitiveness and growing financial vulnerability; and on regulatory failures in banking. Then we take a leaf from Charles Kindleberger's book (1996) on Panics, Manias and Crashes and discuss - with historical precedents - various types of financial crisis: speculative attacks on pegged exchange rates, asset bubbles, stock market crashes and bank runs. Based on the distinction between illiquidity, due to a shortage of cash, and insolvency arising from a failure of economic prospects, we go on to outline three main views of the current crisis.

First that it was simply due to reversal of capital flows, to a failure of collective action on the part of creditors which could and should have been solved by supplying extra liquidity - or by forcing creditors to rollover their loans. Second the view that the miracle had grown into a bubble that finally had to burst: so the problem was essentially one of insolvency. Finally the view that we prefer, that the panic was not wholly groundless (and rescue efforts were bound to be difficult) mainly because weak regulation combined with implicit deposit guarantees had left local bankers free to gamble with the money that global capital markets had poured into their parlours. Panic set in when foreign depositors realised that there were not enough dollar reserves left for the guarantee to be credible. This account (championed most notably by Paul Krugman of MIT) involves both illiquidity and insolvency and helps to explain why the IMF was unwilling simply to throw money at the problem.

Why did the crisis spread like wild-fire around the region? Was it because a bank run due to shaky fundamentals in one country was imitated elsewhere, as investors joined the herd heading for the exit? This and other accounts of contagion are discussed before turning to ideas for crisis prevention and management, and a brief account of future prospects for the region. The paper concludes by outlining immediate steps to resolve the current financial crisis and by proposing international monetary reforms to prevent a recurrence. 
"Theories without facts are empty: facts without theories are blind". Immanuel Kant in the Critique of Pure Reason

\section{Introduction}

What is so special about the East Asian crisis? Radelet and Sachs (1998a, p.1) provide a graphic answer as follows: "The East Asian financial crisis is remarkable in several ways. The crisis has hit the most rapidly growing economies in the world. It has prompted the largest financial bailouts in history. It is the sharpest financial crisis to hit the developing world since the 1982 debt crisis. It is the least anticipated financial crisis in years".

After a brief account of the facts in section 2, we outline various types of financial crisis (section 3). Then in section 4, we ask which theory best fits the facts. Was the East Asian crisis essentially creditor panic where a mad scramble for liquidity brought inherently sound financial and economic system to its knees as Radelet and Sachs (1998b) suggest? ; or was the miracle indeed flawed by fundamental problems in asset prices and resource allocation? We conclude that both factors played a role: there was certainly a creditor panic, but it was in large part due to economic excesses in the domestic private sector and inadequate regulatory responses by the government, particularly in respect of banking. Section 5 discusses how contagion can occur in environments where investors are poorly informed and each looks to the others for guidance. Various approaches to crisis prevention and management are outlined in section 6 . Then, after a brief look at prospects for recovery, the paper concludes with immediate steps that might help resolve the current crises; and with proposed reforms to the international monetary system to prevent a recurrence.

\section{Main features of East Asian crises}

Calvo and Goldstein (1996, p.25) have noted that "in a sense, every financial crisis can be regarded as a failure of the early warning system". But the early warning macroeconomic indicators that were relevant for the 1994/5 Mexican crisis - too much consumption (too low saving), persistent budget deficit and high rate of inflation - did not apply in the East Asian economies. So those seeking the main-springs of the recent crisis need to look elsewhere - at the weakness of financial system, for example, due to inefficient and inadequate regulation and (implicit or explicit) government guarantees. 
This has led many critics to conclude that the problems these countries face today arise not because government did too much, but because they did too little. Put differently, the roots of the crisis lie in private sector activities ${ }^{1}$. The build-up of shortterm foreign liabilities (on an unhedged basis) during economic boom, and the misallocation to unsound projects and non-productive sectors exposed these economies to a sudden loss of confidence. When it came, the capital outflows, together with the depreciation of local currency and collapse of asset prices, exacerbated the financial position of the private sector and the crisis proved self-fulfilling.

In this section, we provide a summary of the four main elements that contributed to the onset of the crisis in East $\mathrm{Asia}^{2}$; specifically a) external factors and macroeconomic imbalances, b) private capital inflows, c) the role of financial intermediation, and d) the behaviour of asset prices.

\section{a) External factors and macroeconomic imbalances}

East Asian countries have enjoyed an impressive economic performance for several decades: in Korea, Indonesia and Thailand - the countries we focus on in this section - GDP grew at around 8-9 percent per annum from the beginning of the 1990s till 1996. In Korea, the rapid growth in output - of chips, ships, and cars, for example - was backed by rapid capital accumulation financed by a high rate of domestic saving - about 35 percent of GDP. Thai residents also saved about the third of their income and invested even more: Indonesians saved and invested just over a quarter of their income (see Appendix 1). Public sector deficits have often been preceded currency crises, as in Mexico 1994/5: but this was not the case in East Asia. Through the 1990s, government budgets were more or less in balance in Korea and Indonesia, and in surplus in Thailand (see Table 1). Moreover, the rate of inflation in these countries was kept relatively low.

Until 1997, macroeconomic management in most emerging markets - including Korea, Indonesia and Thailand - involved effectively pegging the exchange rate against the US dollar even though, as the dollar appreciated against the yen - by 50 percent from mid 1995 to end 1997 - this led to an increasing loss of trade competitiveness

\footnotetext{
${ }^{1}$ See the statement given by Joseph Stiglitz in the Meeting of Finance Ministers of Asean plus 6 with the IMF and the World bank (December 1, 1997).
} 
and export shares. Other external factors also played a role in the build-up of pressures in 1996 and early 1997, namely the cyclical slowdown in world trade and disappointingly low growth in Japan, for example. The consequence was persistent and widening current account deficits, and, in 1996, the end of export growth for both Korea and Thailand.

Table 1: Selected macroeconomic indicators

(Annual percentage change unless otherwise noted)

\begin{tabular}{|c|c|c|c|c|c|c|c|c|c|}
\hline Korea & 90 & 91 & 92 & 93 & 94 & 95 & 96 & 97 & 98 \\
\hline Real GDP growth & 9.5 & 9.1 & 5.1 & 5.8 & 8.6 & 8.9 & 7.1 & $5.5^{\mathrm{e}}$ & $-3.6^{\mathrm{f}}$ \\
\hline Inflation & 8.6 & 9.3 & 6.2 & 4.8 & 6.3 & 4.5 & 4.9 & $4.4^{\mathrm{e}}$ & $12.5^{\mathrm{f}}$ \\
\hline Domestic saving $^{1}$ & 36.1 & 35.9 & 35.1 & 35.2 & 34.6 & 35.1 & 33.3 & - & - \\
\hline Gov't budget balance $^{1}$ & -0.7 & -1.6 & -0.5 & 0.6 & 0.3 & 0.3 & -0.1 & - & - \\
\hline Export growth $^{2}$ & 4.2 & 10.5 & 6.6 & 7.3 & 16.8 & 30.3 & 3.7 & - & - \\
\hline Current account balance $^{1}$ & -0.9 & -3.1 & -1.6 & 0.2 & -1.3 & -2.1 & -5.0 & $-1.9^{\mathrm{e}}$ & $6.9^{\mathrm{f}}$ \\
\hline Real exchange rate ${ }^{3}$ & 100 & 99 & 94 & 93 & 91 & 88 & 88 & 157 & \\
\hline Indonesia & 90 & 91 & 92 & 93 & 94 & 95 & 96 & 97 & 98 \\
\hline Real GDP growth & 9.0 & 8.9 & 7.2 & 7.3 & 7.5 & 8.2 & 8.0 & $7.0^{\mathrm{e}}$ & $-10.0^{f}$ \\
\hline Inflation & 7.8 & 9.4 & 7.5 & 9.7 & 8.5 & 9.4 & 7.9 & $6.6^{\mathrm{e}}$ & $60.0^{f}$ \\
\hline Domestic saving $^{1}$ & 27.9 & 28.7 & 27.3 & 31.4 & 29.2 & 29.0 & 28.8 & - & - \\
\hline Gov't budget balance $^{1}$ & 0.4 & 0.4 & -0.4 & 0.6 & 0.9 & 2.2 & 1.2 & - & - \\
\hline Export growth $^{2}$ & 15.9 & 13.5 & 16.6 & 8.4 & 8.8 & 13.4 & 9.7 & - & - \\
\hline Current account balance ${ }^{1}$ & -2.8 & -3.5 & -2.3 & -1.6 & -1.8 & -3.4 & -3.4 & $-5.0^{\mathrm{e}}$ & $7.3^{\mathrm{f}}$ \\
\hline Real exchange rate ${ }^{3}$ & 100 & 99 & 92 & 88 & 92 & 89 & 80 & 150 & - \\
\hline Thailand & 90 & 91 & 92 & 93 & 94 & 95 & 96 & 97 & 98 \\
\hline Real GDP growth & 11.6 & 8.1 & 8.2 & 8.5 & 8.9 & 8.7 & 6.4 & $0.5^{\mathrm{e}}$ & $-4.2^{\mathrm{f}}$ \\
\hline Inflation & 6.0 & 5.7 & 4.1 & 3.4 & 5.1 & 5.8 & 5.9 & $5.6^{\mathrm{e}}$ & $15.0^{\mathrm{f}}$ \\
\hline Domestic saving $^{1}$ & 32.6 & 35.2 & 34.3 & 34.9 & 34.9 & 34.3 & 33.1 & - & - \\
\hline Gov't budget balance $^{1}$ & 4.5 & 4.7 & 2.8 & 2.1 & 1.9 & 2.9 & 2.3 & - & - \\
\hline Export growth $^{2}$ & 14.9 & 23.2 & 14.2 & 13.3 & 22.7 & 25.1 & -1.3 & - & - \\
\hline Current account balance ${ }^{1}$ & -8.3 & -7.8 & -5.7 & -5.1 & -5.7 & -8.1 & -8.0 & $-3.5^{\mathrm{e}}$ & $7.9^{f}$ \\
\hline Real exchange rate ${ }^{3}$ & 100 & 97 & 90 & 88 & 89 & 87 & 80 & 124 & - \\
\hline \multicolumn{10}{|c|}{$\begin{array}{l}{ }^{1} \text { In percent of GDP } \\
{ }^{2} \text { based on nominal US dollar } \\
\text { based on WPI; trade-weighted, } 1990=10 \\
\text { e } \text { (JPMorgan) estimate } \\
\text { f (JPMorgan) forecast } \\
\text { Sources: IMF (1997), Radelet and Sach }(1998 a, b) \text {, and JPMorgan, Asian Financial Market report, } \\
2 Q 98 .\end{array}$} \\
\hline
\end{tabular}

\footnotetext{
${ }^{2}$ For extensive reviews of the East Asian crisis, see Bhatttacharya et al.(1998), Corsetti et al.(1998), and Radelet and Sachs (1998a,b).
} 


\section{b) Net capital flows to East Asia}

In the past decade, emerging markets around the world have received substantial capital flows from industrial countries. The figures for net private capital inflows to East Asia in Figure 1 shows inflows averaging between 1 and 3 percent of GDP in the 1980s, rising to levels ranging from 5 percent of GDP for Korea to 10 percent for the Philippines by 1996. This surge was both large and persistent: Malaysia and Thailand, for example, received private capital inflows averaging about 9 and 10 percent of GDP for the six-year period, 1989-95.

Figure 1: Net private capital inflows

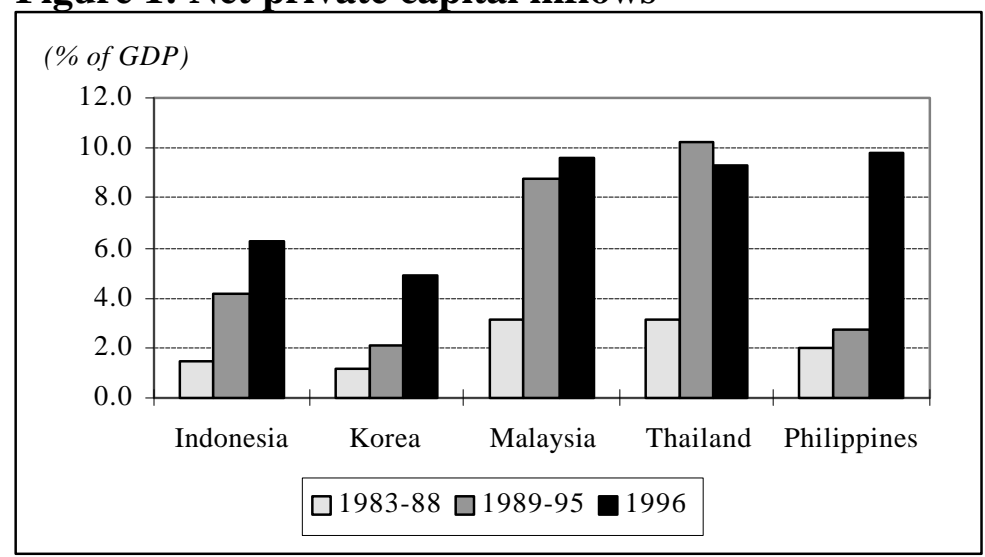

Source: World Economic Outlook, IMF, December 1997.

The composition of these flows, as between equity investment and private lending, can be seen from Table 2. In the three years 1994-96, net external financing came to 221 billion dollars: direct investment played a small role relative to portfolio investment and commercial bank lending of 129 billion. But foreign currency reserves increased by only 23 billion, leaving these economies highly exposed to any reversal in capital flows. 
Table 2: Five Asian Economies ${ }^{1}$ : Net Capital Flows

(billions of US\$)

\begin{tabular}{|c|c|c|c|c|c|}
\hline & 94 & 95 & 96 & $97 \mathrm{e}$ & $98 \mathrm{f}$ \\
\hline Current account balance & $\underline{-24.6}$ & -41.3 & $\underline{-54.9}$ & $\underline{-26.0}$ & $\underline{17.6}$ \\
\hline External financing, net & $\underline{47.4}$ & $\underline{80.9}$ & $\underline{92.8}$ & $\underline{15.2}$ & $\underline{15.2}$ \\
\hline Net private flows & 40.5 & 77.4 & 93.0 & -12.1 & -9.4 \\
\hline Equity investment & 12.2 & 15.5 & 19.1 & -4.5 & 7.9 \\
\hline Direct equity & 4.7 & 4.9 & 7.0 & 7.2 & 9.8 \\
\hline Portfolio equity & 7.6 & 10.6 & 12.1 & -11.6 & 1.9 \\
\hline Private creditors & 28.2 & 61.8 & 74.0 & -7.6 & -17.3 \\
\hline Commercial banks & 24.0 & 49.5 & 55.5 & -21.3 & -14.1 \\
\hline Non-bank private creditors & 4.2 & 12.4 & 18.4 & 13.7 & -3.2 \\
\hline Net official flows & 7.0 & 3.6 & -0.2 & 27.2 & 24.6 \\
\hline Int'l financial institutions & -0.4 & -0.6 & -1.0 & 23.0 & 18.5 \\
\hline Bilateral creditors & 7.4 & 4.2 & 0.7 & 4.3 & 6.1 \\
\hline Resident lending/other, net ${ }^{2}$ & $\underline{-17.5}$ & $\underline{-25.9}$ & $\underline{-19.6}$ & -11.9 & $\underline{-5.7}$ \\
\hline $\begin{array}{l}\text { Reserves excl.gold } \\
(-=\text { increase })\end{array}$ & -5.4 & $\underline{-13.7}$ & $\underline{-18.3}$ & $\underline{22.7}$ & $\underline{-27.1}$ \\
\hline
\end{tabular}

How big the reversal in private capital flows was to prove is documented in line 3 of the table: there was a dramatic 105 billion dollar turn-around, from an inflow of 93 in 1996 to an outflow of about 12 in 1997, with commercial bank lending playing a major role (see line 6). "As confidence eroded towards the end of 1997, maturing short-term debt was not fully rolled over for a number of economies, especially South Korea and Indonesia. This resulted in an estimated net outflow of $\$ 21$ billion to commercial banks in 1997 for the five economies as a group, compared with inflows of about $\$ 56$ billion in 1996," (IIF, 1998, p.2). Portfolio investment also showed a dramatic reversal from an inflow of 12 billion in 1996 to an outflow of the same size the next year. 


\section{c) The role of financial intermediation}

As Radelet and Sachs (1998a, p.15) argue, "probably the biggest signs of growing risk were in the financial sector", and we agree with this view. As already been mentioned, unhedged borrowing in foreign currency was on-lent in local currency, exposing banks to currency risk. In addition, imprudent lending also played a role in the build-up to the crisis.

The expectation that national governments and international financial institutions would rescue failing banks (and non-banks) seemed to have engendered excessive risk-taking. Firms that face a decline in their net equity have an incentive to 'gamble for resurrection' and this moral hazard problem applies particularly in the case of banks. (We discuss later how this can give rise to creditor panic and currency collapse.)

Three indicators track the growing vulnerability of the financial sector in these East Asian economies: first, there is the increase in short-term foreign borrowing; second, the rapid rise in bank credits to private sector; and third, the high exposure to risky and unprofitable lendings. By mid of 1997, short-term external debt relative to liquid foreign assets (foreign exchange reserves) was as much as 2.1, 1.7, and 1.5 in Korea, Indonesia and Thailand respectively, see Figure 2. Thanks to capital market liberalisation, bank lending to the private sector grew rapidly, so that, by end 1996, financial claims on the private sector stood well above 100 percent of GDP in Korea and Thailand (Table 3). (Indonesia offers a striking contrast; this was because large domestic corporations borrowed directly off-shore.)

Figure 2: Short-term external debt (June 1997) (In percent of foreign exchange reserves)

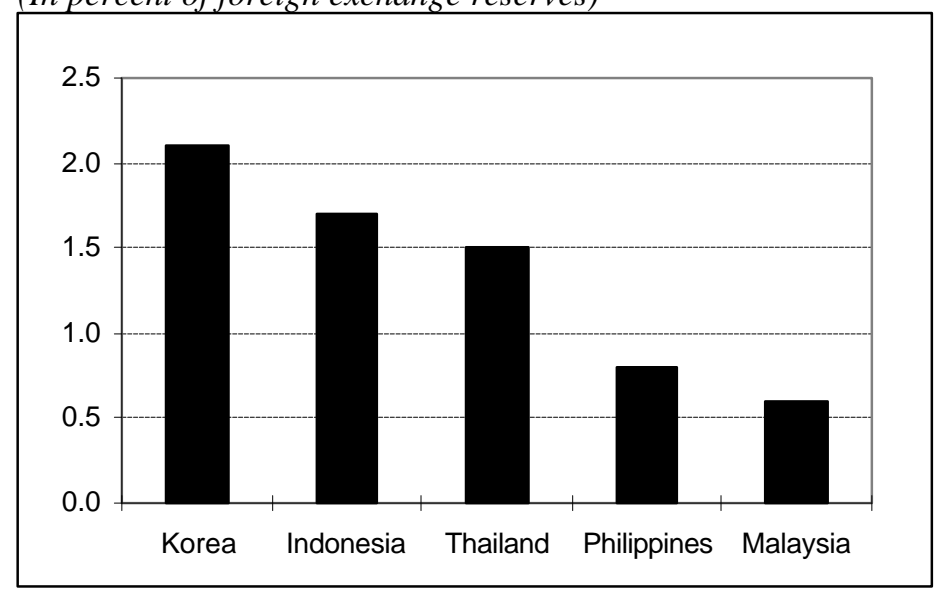

Source: BIS. 
Table 3: Financial claims on private sector

(In percent of $G D P$ )

\begin{tabular}{lrrrrrr}
\hline & 1991 & 1992 & 1993 & 1994 & 1995 & 1996 \\
\hline Korea & 103.1 & 110.7 & 121.3 & 128.8 & 133.5 & 140.9 \\
Indonesia & 50.7 & 49.5 & 48.9 & 51.9 & 53.7 & 55.8 \\
Thailand & 88.6 & 98.4 & 110.8 & 128.1 & 142.0 & 141.9 \\
\hline \multicolumn{4}{l}{ Source: Radelet and Sachs $(1998 a)}$.
\end{tabular}

As for the third indicator, there was a growing dependence of the banking sector on property lending: in Indonesia, for example, loans to real estate sector grew at an annual rate of 37 percent during 1992-5, compared with 22 percent for total bank credit (Montgomery, 1997); and in Thailand, the growth of lending by finance companies to property sector averaged 41 percent per annum, compared with total lending growth of 33 percent per annum during 1990-5. So there was a marked shift in the composition of Thai finance companies' loan portfolio; the percentage share of property loans increased from 15 percent to about 24 percent while manufacturing loans steadily declined from 22 percent to 15 percent during 1988-96 (see Figure 3).

In Korea, however, the growing risk was due to excessive lending in the manufacturing sector, concentrated in large corporate conglomerates (chaebol). As can be seen in Figure 4, companies in this sector relied heavily on debt rather than equity; the debt to equity ratio was as high as 317 percent at the end of 1996 -- the comparable figure for the US is around 100 percent, Corsetti et al. (1998, p.20). Private banks kept on lending to the chaebol despite the decline in their profit margins over several years [the profit margin (profit over sales) for the top 30 chaebol in 1996 stood at only 0.2 percent (Bhattacharya et al. (1998, p.50)]. It is worth adding that "the vulnerability of the [Korean] banking system was increased not only by large exposures to chaebol, but also by directed lending ..., politically influenced lending, and regulations and institutional borrowing through the financial system for on-lending to corporations", (IMF, 1997, p.12). 
Figure 3: Loans to real estate and manufacturing sectors by Thai finance companies

(Share of total outstanding loans)

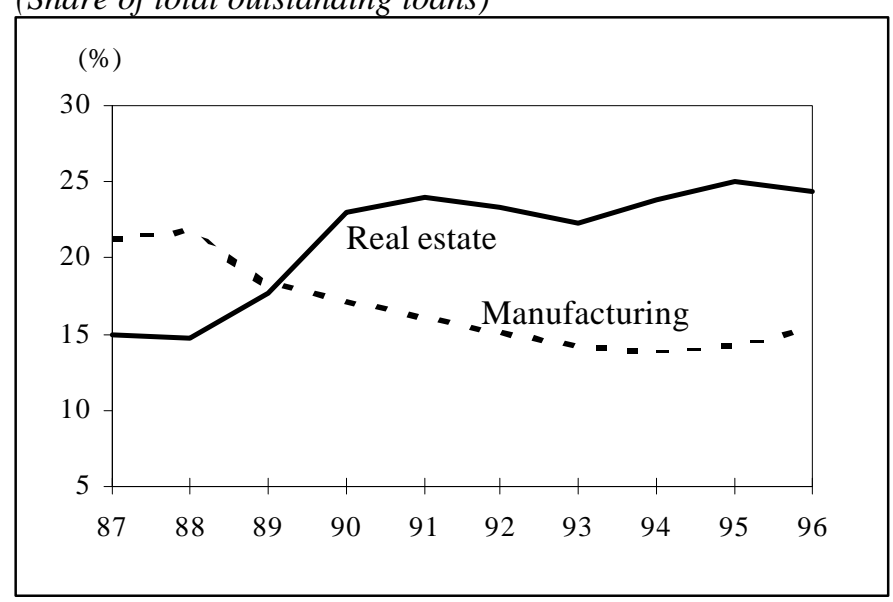

Source: Bank of Thailand.

Figure 4: Debt to equity ratio in Korea manufacturing sector

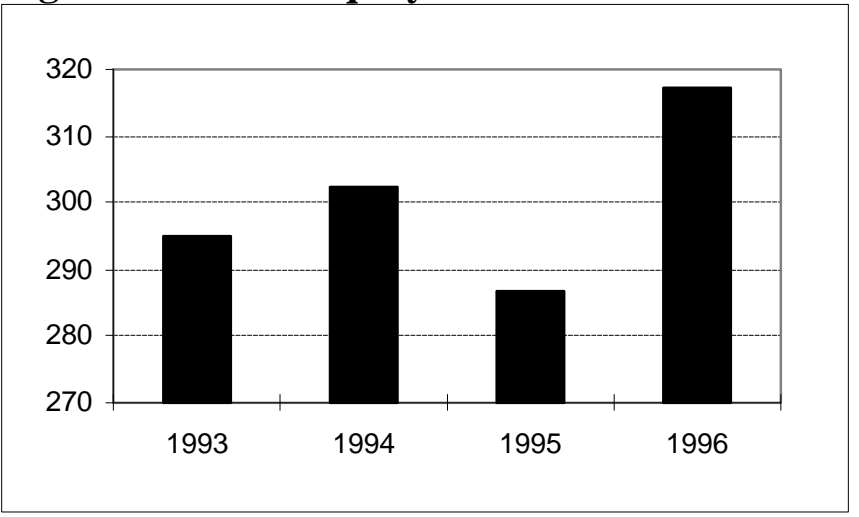

Source: Bank of Korea.

\section{d) Asset prices}

Asset prices can play a key role both in signalling concern ex ante and in exacerbating problems when the crisis occurs. Here, we briefly describe the behaviour of equity prices, property values and exchange rates in Korea, Indonesia and Thailand.

\section{i. Stock markets}

Although the timing and the severity of the crisis came as a surprise, some stock markets in the region had been signalling caution for some time as can seen from Figure 5 (using a base of 100 in January 1990). The stock market in Thailand, for example, having risen to a plateau of about 150, began falling in early 1996 so that by early 1997 it was standing below 100. It has fallen significantly since, to around 50. In Korea, the KOSPI index has shown a similar pattern except that the plateau was only 
about 100 before the fall in 1996 and the collapse in 1997. (By contrast, the Indonesian stock market gave little indication of the coming crisis: rising through 1995 and 1996 to reach a peak of about 180 in mid 1997.)

\section{Figure 5: Stock market indices}

$(1 / 1 / 90=100)$

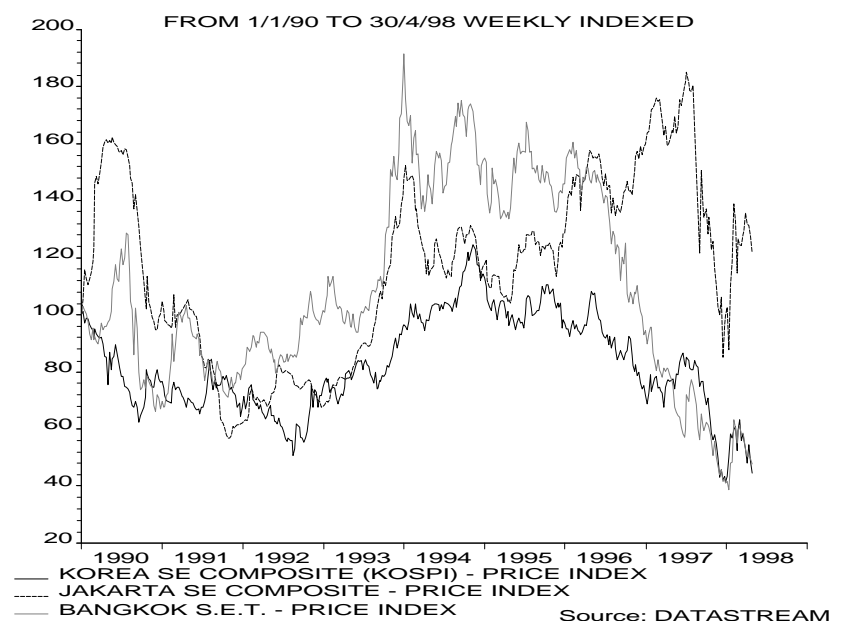

\section{ii. Property markets}

Currency crises have often been preceded by a boom-bust cycle in asset prices, and this was true in East Asia. Property prices (measured by prime office capital values) surged rapidly during 1988-91 both Thailand and Indonesia (see Figure 6). Although the downturn of real estate sector began as early as 1991-2, prices did not drop sharply until 1997 . Why not? The reason appears to be that the market was not allowed to clear. In Thailand, for example, there is evidence of massive oversupply in office, condominium and residential property with high rates of vacancy, but the Thai finance companies kept rolling over their loans during 1993-96 rather than forcing property companies into bankruptcy ${ }^{3}$.

\footnotetext{
${ }^{3}$ According to data from Jones Lang Wooton, the average sales price in Bangkok for office space fell by 30.2 percent in local currency term during the second half of 1997 which is modest compared to the fall in value of property companies in the stock market. They commented, however, that "prices have held up artificially because of the lack of transactions. Local owners are reluctant to place properties for sale into a falling market. There are very few local buyers and most overseas investors have adopted a 'wait and see' attitude, given the falling value of the Baht. The Thai property market is inefficient, the legal system is slow to move against insolvent owners or developers and the Government is reluctant to move against powerful vested interest groups", (Jones Lang Wooton, Regional Property Market in 1998, p.32).
} 
Figure 6: Prime office capital values* $(1988=100)$

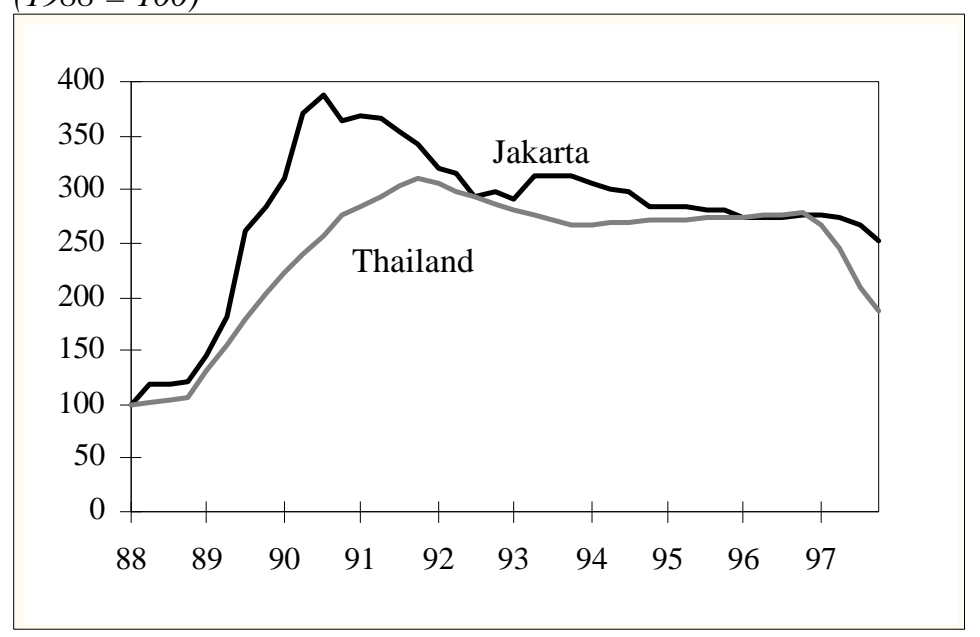

* Index in local currency

Source: Jones Lang Wooton.

Perhaps a more telling indicator is the share value of property companies in the stock markets. As shown in Table 4, the share price of the property companies in Thailand fell significantly by about 68 percent during four quarters before the abandonment of Thai baht on 2 July; and by the year property companies in Thailand were worth only 10 percent of their value 24 month before. (Although, property share index in Indonesia showed an upward trend from September 1996 until June 1997, it sharply declined by 58 percent during the second half of the year.)

Table 4 : Share value of property companies in stock markets

\begin{tabular}{lrrrrrrr}
\hline & $2 \mathrm{Q} 96$ & $3 \mathrm{Q} 96$ & $4 \mathrm{Q} 96$ & $1 \mathrm{Q} 97$ & $2 \mathrm{Q} 97$ & $3 \mathrm{Q} 97$ & $4 \mathrm{Q} 97$ \\
\hline Indonesia & & & & & & & \\
Index & 137 & 135 & 144 & 160 & 170 & 104 & 72 \\
$\begin{array}{l}\text { Percentage change } \\
\text { Thailand }\end{array}$ & & -1.3 & 6.2 & 11.2 & 6.4 & -38.9 & -30.7 \\
Index & 833 & 720 & 524 & 328 & 232 & 224 & 96 \\
Percentage change & & -13.6 & -27.3 & -37.4 & -29.2 & -3.4 & -57.4 \\
\hline Source: Datastream. & & & & & & &
\end{tabular}

\section{iii. Foreign exchange markets}

In response to capital inflows during the 1990s, central banks intervened to prevent exchange rate appreciation; and later, when capital flows went into reverse, central banks used their foreign exchange reserves to resist downward pressure on the exchange rate - as long as reserves lasted. The relative stability of nominal exchange rates against the US dollar until the crisis erupted is shown in Table 5. The cost of the 
dollar in Thai baht, for example, was unchanged between the end of 1993 and 2Q97.

The loss of competitiveness as the dollar rose against the yen is also shown: in

Thailand, for example, the index of competitiveness (the real exchange rate) fell from 87 in 1995 to 76 just before the crisis.

Table 5: Nominal and Real exchange rates

(End-of-period price of US\$)

\begin{tabular}{rrrrrrr}
\hline & \multicolumn{2}{c}{ Korea } & \multicolumn{3}{c}{ Indonesia } & \multicolumn{3}{c}{ Thailand } \\
\hline & Nominal & Real & \multicolumn{2}{c}{ Nominal $^{\text {Real }}{ }^{1}$} & Nominal $^{\text {Real }}{ }^{1}$ \\
1993 & 811 & 93 & 2112 & 88 & 25.6 & 88 \\
1994 & 793 & 91 & 2203 & 92 & 25.1 & 89 \\
1995 & 776 & 88 & 2289 & 89 & 25.2 & 87 \\
1996 & 848 & 88 & 2361 & 80 & 25.7 & 80 \\
1 Q97 & 896 & 89 & 2401 & 75 & 26.0 & 75 \\
2Q97 & 888 & 89 & 2432 & 78 & 25.9 & 76 \\
3Q97 & 914 & 88 & 3270 & 99 & 36.3 & 104 \\
4Q97 & 1695 & 157 & 5650 & 150 & 46.8 & 124 \\
1 Q98 & 1385 & - & 8650 & - & 39.3 & - \\
& & & & & & \\
Peak & 1960 & - & 15450 & - & 56.7 & - \\
& $23 / 12 / 97$ & & $23 / 01 / 98$ & & $12 / 01 / 98$ & \\
\hline
\end{tabular}

${ }^{1}$ based on WPI; trade-weighted, 1990=100

Sources: Datastream, Radelet and Sachs (1998a) for real exchange rates.

After currency crisis began in early July, the cost of the dollar rose by more than 30 percent in Baht and Rupiah (but only 3 percent for Korean won). All three currencies then went into a downward spiral: so, at its peak, the dollar was worth 120 percent more in Thailand and Korea and 535 percent more in Indonesia than it was in 2Q97. Subsequently, however, both the baht and the won have recovered sufficiently to reduce the cost of the dollar below its end 1997 level: but this is not, of course, true for the Indonesian rupiah (see Box A). 


\section{Box A: The special case of Indonesia}

The case of Indonesia, where the collapse of the exchange rate has been so profound and the attendant risks so great, seems to merit special consideration. Thanks to the commanding role of the presidential family in the economy, the diversion of financial resources and misallocation of investment was much more profound than in Korea and Thailand.

Moreover, the fall of the currency seemed to precede the bank crisis and it surprised the hedge funds (who are rumoured to have lost on the rupiah). The episode looks startlingly reminiscent of a stock market crash, where falling asset values trigger the exit of stop-loss traders ${ }^{4}$.

A key role was played by the ethnic minority of resident Chinese, which constitutes only 4 percent of the population but controls the majority of Indonesia's largest companies. They know that they are envied by many of those less fortunate; and they cannot forget that half a million people were killed when ex-president Suharto gained power in 1966. So, when the currency began to fall, there were good reasons for exit. It was not just that they might lose their assets: their livelihoods - indeed their lives - were at risk. But capital flight by one group can easily trigger exit by others, as seems to have happened. US investors, seeing the collapse, decided to get out and dump the rupiah. So there was an avalanche of selling which drove the rupiah down to alarming depths. It fell from a rate of about 2400 against the dollar before the crisis to rate of over 15000 at its lowest point. It seems that neither the hedge funds nor the US banks had anticipated the avalanche, as they lost substantial sums of money in the process. How is it that these sophisticated players got caught out? Presumably it is because they failed to factor the fears of ethnic minorities (under a corrupt and dictatorial regime) into their calculations of market behaviour.

Another factor is that regulatory action can sometimes trigger panic rather than calm. Radelet and Sachs (1998b, p.34) argue in particular that "the bank closures in Indonesia provoked a financial panic and a run on the entire private-sector banking system other than the foreign-owned banks". (Sixteen commercial banks were suddenly closed with the explicit proviso that deposits over 20 million Rupiah - approximately 5000 dollars at the time - would be unprotected.) Stable doors need to be closed before, not while, the horses are bolting!

\footnotetext{
${ }^{4}$ This analogy also pursued in Krugman and Miller (1993) where a stop-loss model is used to explain a crash in exchange rate, made worse by the 'cascade effect' (of early exit triggering an avalanche of further exit).
} 


\section{Varieties of currency and financial crisis}

One of the most salient features of the Asian economies being discussed was the collapse of their exchange rates against the dollar. This encouraged many observers to identify the crisis as a speculative attack on a fixed exchange rate, for which two distinct kinds of explanations had already been developed. According to the first of these, an exchange rate crisis reflects an irreconcilable conflict between the needs of public sector finance and the preservation of a fixed exchange rate, leading to continuous reserve depletion ${ }^{5}$. While this may have fitted earlier currency crises in Argentina and Mexico, as indicated in the first row of Table 6, it seems quite inappropriate for East Asian economies for two reasons: first, the economies concerned were typically models of fiscal rectitude and second the currency crisis came as a surprise.

More promising perhaps was the second explanation in terms of self-fulfilling speculative attack, developed to account for the largely unanticipated collapse of European Exchange Rate Mechanism in 1992, by Maurice Obstfeld $(1994,1996)$ in particular. In this case, a currency crisis involves an unanticipated shift from one equilibrium (a peg) to another (a float) ${ }^{6}$. As applied to the ERM crisis, the government was faced with the choice between sticking to an exchange rate peg (with no output stabilisation) and a surprise devaluation which would create extra jobs: in conditions of high unemployment, it would not take much to lead people to expect the latter and it would be optimal for the government to behave accordingly, i e., self-fulfilling. As Obstfeld and Rogoff (1997, p.652) point out "With multiple equilibria some seemingly unimportant event could trigger an abrupt change in expectations, shifting the equilibrium... Such an event would look much like [a] sudden speculative attack on [the] exchange rate". While self-fulfilling expectations surely played a role, it seems inadequate to describe events as optimal regime choices by the governments concerned.

\footnotetext{
${ }^{5}$ Let the financing of the public sector deficit under a fixed exchange rate - with no inflation involve constant depletion of foreign currency reserves: then recourse to 'inflation taxation' as a means of financing the public sector deficit necessarily involves a predictable change of exchange rate regime. This is the message of the classic paper on speculative attack by Krugman (1979).

${ }^{6}$ What event could trigger such a change in expectations? Was it the sales of sterling by George Soros in September/October 1992?
} 
Table 6 : Currency and financial crises

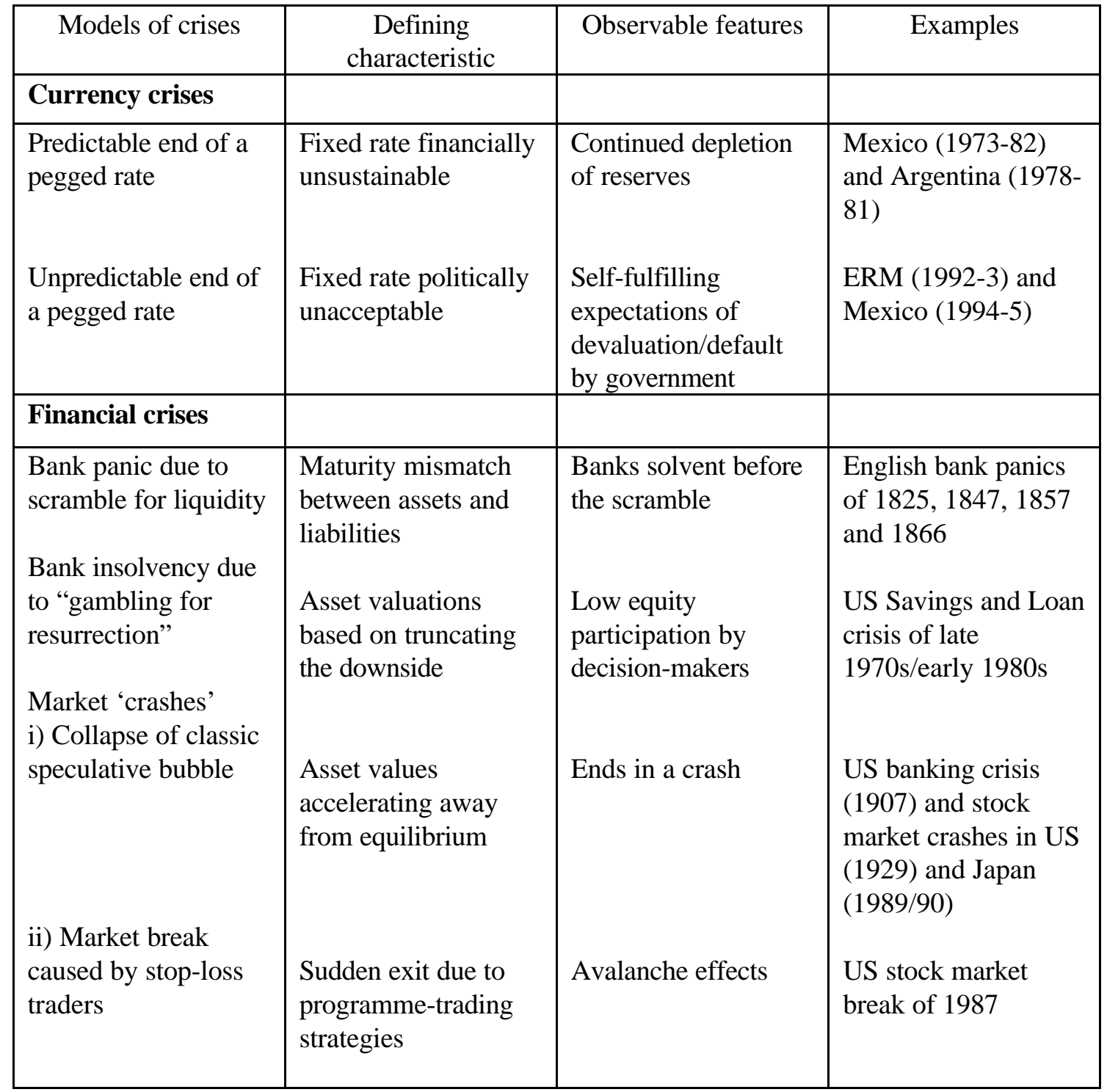


The failure of these two approaches (with their focus on foreign exchange markets and on the public sector) adequately to explain events in East Asia, has led to a radical rethink. Could it be that a blind bank panic brought down a perfectly sound economic system? Or could it be that East Asian miracle was flawed and the fall in the exchange rates was a symptom of its problems? In either case, the explanation involves financial crises in other markets.

The second half of the table, therefore, includes four further types of financial crisis. The first of these is a liquidity crisis, represented by a bank run. While a run on the deposits of a single, solvent bank may be satisfied by disposing of its assets to other banks, this is not true if there is a generalised bank panic affecting the banking system as a whole. In that case, deposit withdrawals can lead to a 'self-fulfilling' financial collapse, with the efforts of all banks to dispose of illiquid assets in a hurry leading to falling asset values and widespread insolvency. The maturity mismatch between shortterm deposits and long-term loans implies that the banking system faces two possible equilibria - survival or collapse: and it can shift from the good to the bad by a failure of collective action (see Radelet and Sachs, 1998b, and the summary in Box B below). It was the succession of English bank panics from 1825 to 1866 that led Walter Bagehot in 1873 to advocate that the central bank should stay the panic by acting as the lender of last resort, i.e., "that in time of panic it must advance freely and vigorously to the public out of its reserve" (Bagehot, 1915, p.187). Friedman and Schwartz (1963) emphasise key role of US bank runs and bank closures in converting a severe downturn into the Great Depression of 1930s (and blame the Federal Reserve for failing to avert it).

The second type of financial crisis shown in the table involves not illiquidity but insolvency. For firms close to bankruptcy, limited liability leads to perverse incentives as shareholders enjoy the profit of upside returns, leaving debtholders with downside risk. For banks or near-banks with low equity, loan managers are tempted to gamble with depositors' money as risky investment becomes even more attractive than safe investment. Bondholders and other creditors will, of course, resist variance-increasing investment strategies - unless the government insures them against losses. In which case, the stage is set for wholesale 'gambling for resurrection', as in the US Savings and Loan debacle of the 1980s. 


\section{Box B: Multiple equilibria, co-ordination failure and forced roll-overs}

Sachs and Radelet (1998b, p.5) argue that "international loan markets are prone to self-fulfilling crises in which individual creditors may act rationally and yet market outcomes produce sharp, costly, and fundamentally unnecessary panicked reversals in capital flows". Why should this be so? Assume creditors as a group would be willing to make a new loan, but no individual creditor is willing to do so unless other creditors do the same: then, with a failure of co-ordination among creditors, it is quite possible that there will be no lending to an illiquid borrower. (Technically, the source of multiple equilibria is pay-off externalities, i.e., the payoffs to an agent adopting increases in the number of other agents adopting the same action, see Devenow and Welch, 1996, pp.605-7.) Table B.1 provides a simple illustration of the argument.

Table B.1: To lend or not to lend?

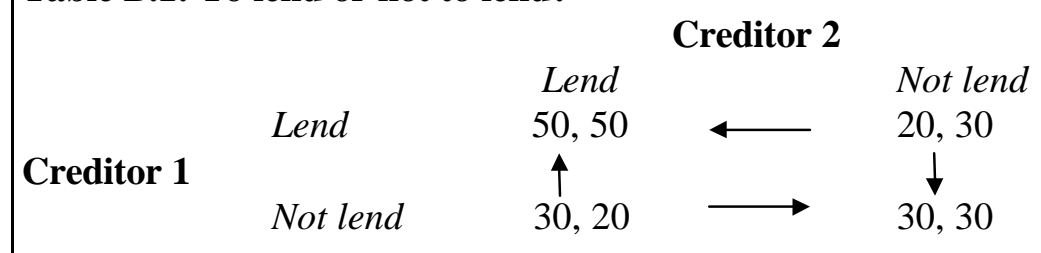

The setting is one in which each of two creditors has lent 50 to a borrower who is solvent but illiquid: solvent because the project will pay 120 in a years time; illiquid because there are no dividends in the meantime. At the beginning of the year, however, the borrower is required to provide a total of 20 as debt service. If each creditor is willing to relend the 10 of debt service received, the project will continue and each will receive future repayments with a present discounted value of 50. But if neither creditor is willing to roll over the loan, the debtor will default and the project will be scrapped with each creditor receiving only 30 from the scrap value. The pay-offs in these two cases are shown in the top-left and bottom-right of the table.

Note that if creditor 1 is willing to lend 10 but not creditor 2, the project will still be scrapped and creditor 1 will be worse off (with a net return of only $30-10=20$, see top-right corner of the table). Likewise, if only creditor 2 is willing to roll over the loan, the pay-offs will as shown at bottom-right. What are the equilibrium outcomes?

The cases of both creditors lending and neither lending are the two Nash equilibria of this game - where a Nash equilibrium is defined as a situation where no creditor has the incentive to deviate from his/her strategy given that the other does not deviate. (The arrows show that neither creditor would logically choose to behave differently from the other.) Clearly, continued lending is the more socially efficient equilibrium; but a failure to co-ordinate will lead to a self-fulfilling liquidity crisis where the debtor is pushed into default, the project is scrapped and each creditor concludes that it was right not to put extra money into a failing project!

In circumstances where continued lending is in the self-interest of the creditors, an enforced roll-over may be an appropriate way of handling the liquidity crisis. The co-ordinated roll-over which saved Korea from default at the end of 1997 provides a topical example of this policy: but the fact that half of a dozen of the chaebol have gone bankrupt suggests that the problem was not simply one of illiquidity. 
Financial crisis can also be provoked by the bursting of an asset bubble which has led market valuations to depart ever further above equilibrium. Such speculative bubble can be sustained for some time because each speculator believes that he/she will be able to get out in time; or because excess capital gains cover the cost of insuring against a crash, (Salant and Henderson, 1978 and Blanchard, 1979): but a return to fundamental valuation involves a crash. The US stock price bubble which ended in 1929 is one example; the Japanese stock market crash of 1990 is another. The Nordic banking crises of the late 1980s and early 1990s were closely associate with the boomand-bust of real estate crises (Drees and Pazarbasioglu (1998), in their account of the crises following financial liberalisation in Norway, Sweden, and Finland, conclude that "the authorities failed to tighten prudential bank regulation and to create an adequate supervisory framework", p.36: so East Asia is not alone !)

Market crashes may also be triggered by stop-loss strategies adopted by traders (see Box C). Assume, for example, that portfolio managers in equity markets are judged by profits they make on their portfolios: then, to avoid reporting large losses, traders may be tempted to 'insure' their portfolios by buying puts or programming stop-loss orders (to sell for cash at a given price trigger). If this practice is widespread, a fall in the market can be grossly exacerbated by programme trading; and many believe that the 1987 stock market crash was attributable to such factors (Krugman, 1987 and Grossman, 1987). 


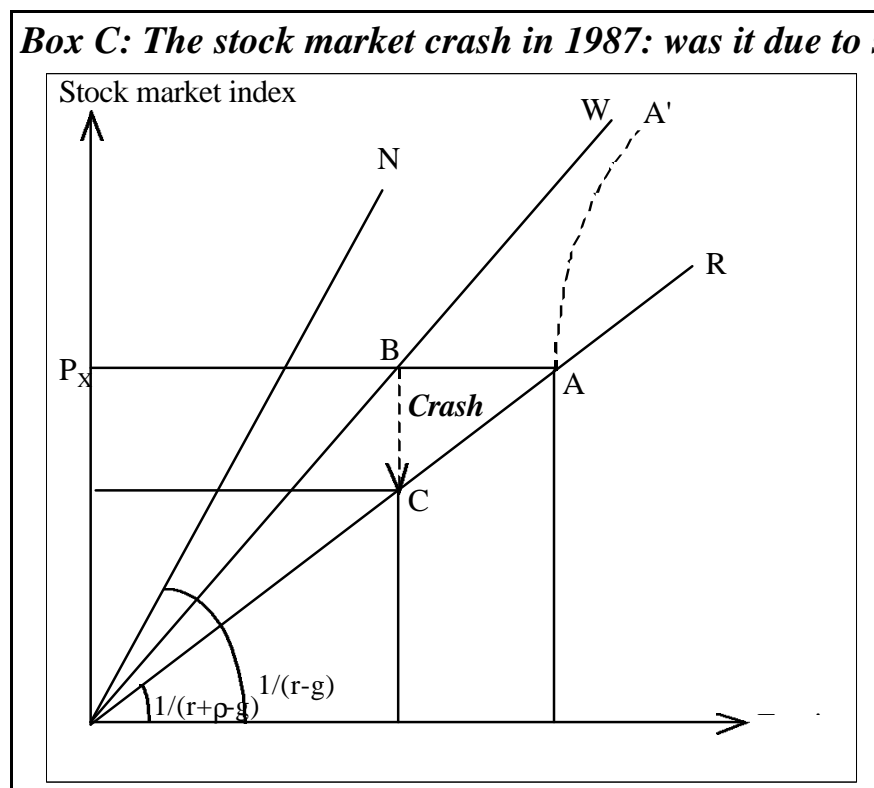

a) Underlying assumptions on market valuation

With real earnings (measured on horizontal axis) following a random walk with an upward trend, g, assume that $\mathrm{p}$, an index of stock market value (plotted on vertical axis) measures the present discounted value of expected future earnings. The schedule labelled ON shows the stock market value if the discount factor is $r$, the riskless real interest rate; while the schedule OR shows the stock market index if the discount factor includes a risk premium, $\rho$, (reflecting the variability of earnings).

Let risk-neutral, stop-loss traders hold $\alpha$ percent of the shares while risk averse, portfolio investors hold the rest. Then the schedule OW, an appropriate weighted average of $\mathrm{ON}$ and OR, would give the value of stocks if $\alpha$ is held constant.

\section{b) Stop-loss orders and the market crash}

Assume for simplicity that all stop-loss traders have a common exit point, $\mathrm{P}_{\mathrm{x}}$, (the trigger price for programme trading and the optimal exercise price for market derivatives - put options). If this is not common knowledge, then the stock market will be valued by the schedule OW to the right of point $B$ : but if and when earnings fall to $E_{c}$, stock market valuation will shift to OR as the stop-loss traders exit. This implies a crash of the stock market (the fall from B to $\mathrm{C}$ in the figure) as the options are exercised and the programme trades kick in. (Genotte and Leland, 1990, develop a similar analysis of the effects of hedging.)

\section{c) Can this happen again?}

George Soros (1996) has argued that the operation of circuit breakers has reduced the attraction of insuring portfolios by program trading, so that such a crash is a one-off event. If the existence of stop-loss traders and their trading strategies are common knowledge, the market should anticipate exit at $\mathrm{P}_{\mathrm{x}}$ and asset values will lie on $\mathrm{AA}$ ' for earnings above $\mathrm{E}_{\mathrm{A}}$ : so when earnings fall to $\mathrm{E}_{\mathrm{A}}$, asset valuation can switch to $\mathrm{OR}$ without any crash. ['Sunshine' trading rules, designed to make clear the position taken by all market participants, are meant to promote common knowledge.] 


\section{Elements of a new approach: illiquidity, insolvency, and moral hazard}

What caused the crisis in East Asia? To help analyse these events, see Figure 7, where the circles indicate two views. The first view, that it was a liquidity crisis, is captured by the circle on the left. The second view, that the miracle was an unsustainable bubble, is on the right. These views need not be mutually exclusive, however, as the truth may involve both factors, interacting in a vicious downward spiral. This is our view.

\section{Figure 7: Characteristics of crises}

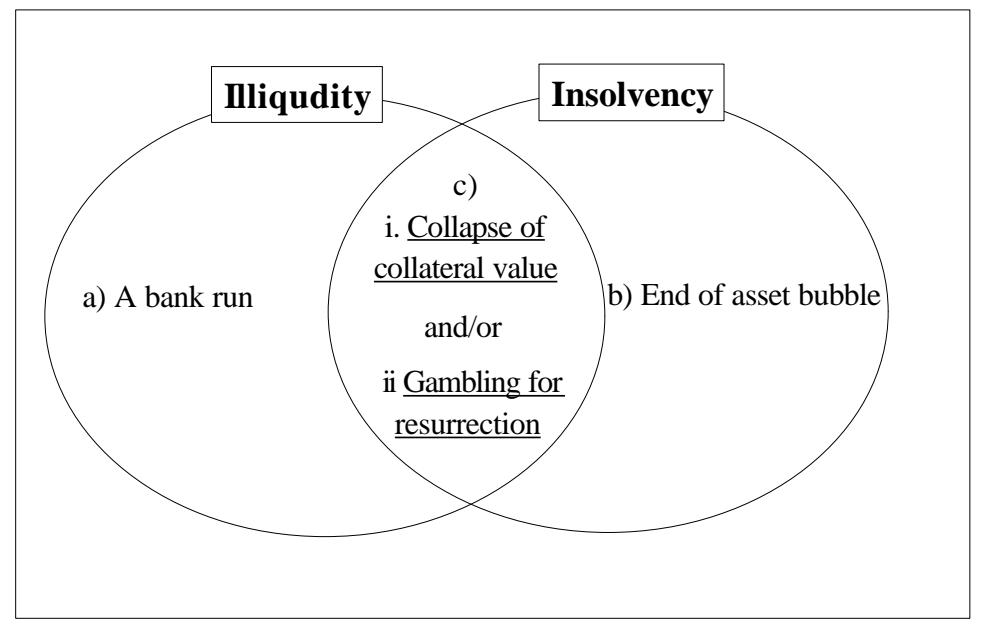

\section{a) A bank run}

Consider first the explanation given by Radelet and Sachs (1998b, p.5) in their recent paper to the Brookings Panel where they advance their preferred explanation that solvent but illiquid borrowers were unable to borrow fresh funds from the capital market in order to make current debt obligations... "The unwillingness or inability of the capital market to provide fresh loans to the illiquid borrower is the nub of the matter." (This view is shown as (a) in the figure.)

By way of theoretical background, they cite the work of Diamond and Dybvig (1983) where bank runs are triggered by exogenous stochastic demands for liquidity by some depositors and not at all by fears of imprudent lending. Banks lend prudently and are essentially solvent, but their investments are illiquid: it is the conflict between the liquidity needs of some depositors and the illiquidity of the bank's assets that can precipitate a bank run. Of course, if the bank run is not checked, illiquidity can become insolvency as banks seek to dump illiquid assets. 
To avert such liquidity-based bank runs, Diamond and Dybvig discuss first the provision of deposit insurance, (as, for example, by the Federal Deposit Insurance Corporation (FDIC) operating in the US since 1934), and second the implementation of a lender-of-last-resort facility by the central bank. Deposit insurance is meant to prevent bank runs -- insured depositors need not withdraw their funds just because they see other doing so ${ }^{7}$ : but, as noted above, recourse to the lender of last resort is how Bagehot recommended bank runs should be managed. In detail, he insisted "First. That loans should only be made at a very high rate of interest"... and "Secondly. That at this rate these advances should be made on all good banking securities, and as largely as the public ask for them" (Bagehot, 1915, pp.187-8); i.e., last-resort lending should be unlimited, at a penalty rate, to solvent banks.

The provision of deposit insurance and lender-of-last-resort facilities are normally the responsibility of national agencies. But with the globalisation of capital markets, there are those who look to the IMF to act as the international lender of last resort, providing reserves to countries facing liquidity crises (see Sachs, 1995).

If the crises in East Asia were just bank panics, could they not have been avoided by appropriate provision of liquidity? And if there was nothing inherently wrong with economic fundamentals, was mis-handled crisis management not to blame for the negative economic fallout? Radelet and Sachs are, indeed, critical of the policies pursued by the IMF (see 'Why did the original IMF programs fail?', Radelet and Sachs, 1998b, pp.33-40); but is it really true that throwing money at the problem was all that was needed?

\footnotetext{
${ }^{7}$ This is not true if the insurance is less than 100 percent or if the guarantee is not fully credible.
} 


\section{b) End of an asset bubble}

Consider instead the second characterisation of the crisis, namely insolvency attributable to the collapse of asset prices as indicated in the right hand side of the figure. Was the East Asian crisis essentially due to the bursting of an asset bubble like the US stock market crash of 1929 ? This view has its attractions ${ }^{8}$, but it is too simple for two reasons. First, the timing is wrong: there was a bubble in stock prices, but stock markets in Korea and Thailand began falling in 1996 not late 1997. Second, it underplays the role of the financial sector in the mis-valuation of assets. (Asset bubbles may exist without necessarily involving the financial sector: one thinks of bubbles in the prices of commodities such as gold or tulips, see Salant and Henderson, 1978, and Garber, 1990.)

The truth, we believe,f is more complex involving perverse financial incentives, distorted asset prices and mis-allocated resources, leading ultimately to a creditor panic. This view is developed in the next section.

\section{c) Illiquidity and insolvency}

Credit market imperfections have been blamed for the depth and persistence of the Great Depression in the U.S.A., Bernanke (1983): when banks failed, no other sources of finance were available. Could similar mechanisms have played a role in ending the East Asian miracle? In this section, we examine features of the financial system which may account for the severity of the economic downturn. First is the amplification of shocks that occurs when borrowing is limited to the value of collateral in the form of land. Second is the incentive for loan managers to mis-direct investment when bank equity is low.

\section{i. Collapse in the value of collateral}

In their model of credit cycles, Kiyotaki and Moore (1997) have shown how credit market imperfections can greatly amplify initial economic disturbances. Specifically, they assume that small businesses, whose main asset is specific human

\footnotetext{
${ }^{8}$ The head-long expansion in the western stock markets over the last year looks more like an asset bubble than a rational reappraisal of future economic prospects. The US stock market, for example, has continued to expand since Alan Greenspan, the chairman of the Federal Reserve, warned about "irrational exuberance"; and despite unemployment of 12 percent, the Italian stock market has more than doubled in one year.
} 
capital, cannot be trusted to repay their loans: so the latter will need to be fully collaterised. This approach has been applied to Thailand in Luangaram (1997) and Edison et al. (1998), where the shocks considered are respectively the fall in exports and the ending of the land price bubble.

There is strong evidence of a land price bubble in Thailand in the period before the crisis. How could the ending of such a bubble lead to a financial collapse? Consider the plight of highly-levered firms, whose loan limits depend on value of collateral in the form of land. The bursting of the bubble which reduces the value of land collateral means that loans are no longer fully collaterised. Banks reduce loan limits accordingly. To repay loans in excess of these limits, borrowers collectively sell land. But this action further reduces land prices, and the sequence may repeat itself until bankruptcy occurs.

This picture of highly-levered, credit-constrained firms illuminates the role that credit markets can play in financial crises like that in East Asia. Excess credit creation can easily raise asset values above equilibrium; but when this disequilibrium is being corrected, credit constraints can set in motion a vicious downward spiral in asset prices, leading to financial collapse.

\section{ii. Gambling for resurrection}

Bank runs in the US Great Depression have been attributed, in part, to the lack of deposit insurance - which is why FDIC was created in 1934. Bank deposits in Thailand and Korea, for example, were not explicitly insured by a deposit insurance corporation but value guarantees were expected beforehand and have in fact been given ex post. Does the existence of this implicit insurance mean that all was well? The answer is unfortunately no. Michael Dooley (1997) highlights the risks facing governments who insure poorly-regulated domestic financial markets: in particular, if substantial foreign money is attracted short-term, an insurance crisis is likely to followed by balance-of-payment crisis as foreign funds are repatriated. The problem is that insurance gives rise to 'moral hazard', i.e., it has incentive effects on behaviour towards risk. Thus bank depositors who are fully insured will have little or no incentive to monitor bank portfolios; and bank shareholders who are protected by limited liability may be tempted to 'gamble for resurrection' (see Box D). 


\section{Box D: Moral hazard, lax bank regulation, and currency collaps $e^{9}$}

Let domestic banks take local and foreign currency deposits and invest them in domestic loans yielding revenues plotted on the horizontal axis of the figure below. If the banks are risk neutral, the value of the loan portfolio (net of fixed costs) is shown by the height of the line VV with slope $1 / r$, where $r$ is the safe rate of interest. Subtracting D, the value of total deposits being invested, gives the schedule $\mathrm{NN}$ which gives the equity value of the banks to the right of B: and if revenues fall to B or below, it should close.

With limited liability and investment in relatively riskless assets, the net equity value of the bank is approximately giving by OBN. But when the net equity of the bank is close to zero loan managers will be tempted to raise it by switching investments so as to increase the variance of returns, as high pay-offs will enhance shareholder profits while losses will be at expense of depositors and bondholders. This behaviour is referred to as 'gambling for resurrection' (see Campbell, 1995 and, with reference to recent crises, Allen and Gale, 1997, and Krugman,1998).

As an illustration, let the alternative investment available to loan managers have positive variance and a negative mean return, $-\mu$, so the value of this investment (less D) is given by line NR with slope $1 /(\mathrm{r}+\mu)$. Note that NR lies everywhere below NN, the value of investing safely. When, if ever, will loan managers be tempted to switch from safe to risky lending which pays a lower rate of interest?

To answer this, let the schedule GG give the equity value of the bank with risky lending when losses are written off by bankruptcy (i.e., it includes the 'put value' implicit in limited liability). The fact that this schedule is higher than NN to the left of S means that risky investments with lower mean return are more attractive than safe investment when bank capital is low. It is when revenues on the safe assets fall to $\mathrm{X}$ that the switch will take place: close to B, managers have almost literally 'nothing to lose' by gambling. Instead closing at point B, they will keep gambling despite the risk of mounting losses, only closing if loan revenue falls to C, with expected losses of CL.

Figure D.1: Moral hazard in banking : "gambling for resurrection"

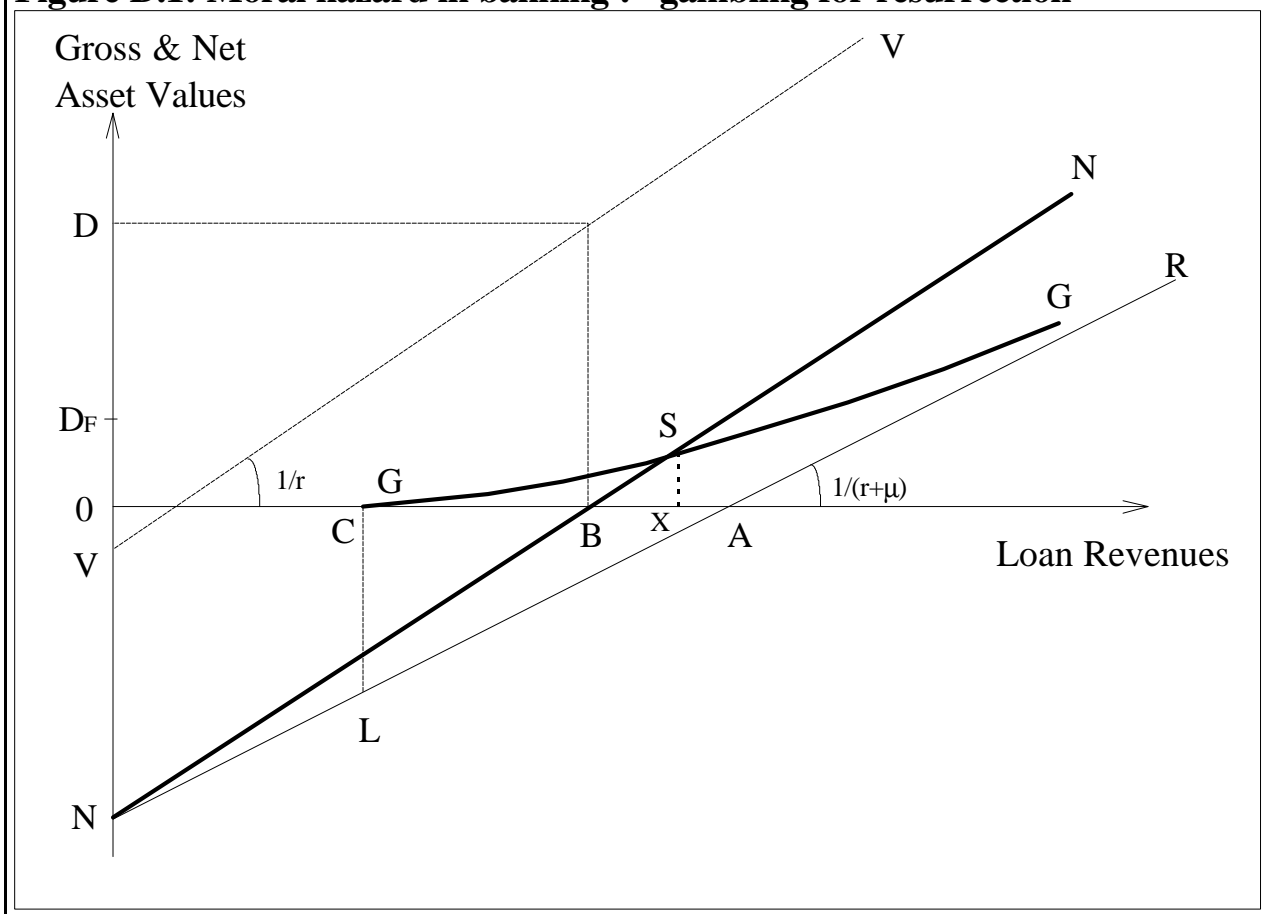

\footnotetext{
${ }^{9}$ This is taken from Bond and Miller (1998).
} 
Who is to prevent loan managers from behaving in this way? Without deposit insurance, it would have to be depositors (and bondholders) who monitor portfolio managers and punish any sign of gambling by withdrawing deposits, for example, or by threatening closure. With insurance, depositors have no incentive to monitor, so it is the government who should monitor portfolio allocation decisions and punish mismanagement.

But, as explained in the text, if returns fall to the switch point $(\mathrm{X})$ and this does not trigger an appropriate regulatory response, this can be the signal for the exit of foreign depositors and a full-blown financial crisis. The danger of allowing or encouraging substantial short-term capital inflows to pour into a weakly regulated banking system is only too apparent: failure to regulate at the switch point can trigger a bank run and currency collapse if foreign deposits $\left(\mathrm{D}_{\mathrm{F}}\right)$ are large relative to foreign currency reserves.

The history of the US Savings and Loan industry in the 1980s bears vivid witness. When President Reagan deregulated the industry, deposit insurance was left in place but loan managers were freed of restrictions on portfolio investment. As a consequence, loan managers who were unwilling to gamble were soon replaced by those who were! And it was not long before practically the whole industry became insolvent, Krugman (1990).

The moral of this tale is that limited liability and insurance provisions designed to avoid financial panic may create severe problems of moral hazard (i.e., in trying to avoid bank runs due to illiquidity, one may end up with insolvency due to gambling for resurrection). To avoid this potentially disastrous outcome, some have suggested restoring the incentives to monitor by removing deposit insurance. As Dewatripont and Tirole (1994) point out, this is a counsel of perfection; most bank deposits are small and depositors are uninformed so they won't or can't monitor. Instead, it is the providers of deposit insurance who must first of all monitor closely the institutions involved and second act swiftly to prevent imprudent lending (by insisting on early closure $^{10}$, for example). Both features were incorporated in the US Federal Deposit Insurance Corporation Improvement Act (FDICIA) passed in 1991, Mazumdar (1997). What about the banking system in East Asia? Alas! the regulatory regime governing banks there was more akin to that of the Savings and Loan industry under President Reagan than to current US banking under FDICIA.

What if the state provides the guarantee but fails to check the moral hazard, as seems to have been true in several East Asian countries? Then (at the very least) local

\footnotetext{
${ }^{10}$ The moral hazard problems arising in the banking industry are analysed by Dewatripont and Tirole (1994), assuming that financial panic can be avoided by a deposit insurance. In their monograph on the prudential regulation of banks, they treat the problem as one of corporate governance and discuss how effective the BIS capital adequacy ratio may be as triggers for regulatory action.
} 
tax payers must expect substantial tax charges to cover the losses of the insurance agency. Provided the agency will be bailed out, local currency depositors may rest assured. But the same may not be true for foreign currency depositors ${ }^{11}$. They see local banks mis-managing their portfolios without any regulatory response and they can forecast bank insolvencies. They also know that, while the local central bank can print domestic currency, it can't print dollars! So, if foreign currency reserves are low relative to foreign currency deposits, the stage is set for a bank run as foreign currency depositors head for safety. And the central bank, having lost all its reserves will be forced to float the currency.

Moreover, the willingness of the IMF to act as a lender of last resort in foreign currency terms is clearly hampered where there is unchecked moral hazard in local banking system. Lending into this situation will not avoid the problem: it may even lead to greater losses for local tax payers (as the $S \& L$ experience suggests).

\footnotetext{
11 "The effective functioning of deposit insurance depends on the deposits being in domestic currency; countries with dollarized banking systems often leave themselves exposed to creditor runs even when some deposit insurance arrangements are in place, because such deposit insurance often lacks adequate reserve funds and therefore credibility", (Radelet and Sachs, 1998b, p.9)
} 
Table 7: Selected severe banking crises, 1980-96

\begin{tabular}{lc}
\hline $\begin{array}{l}\text { Country (time period of } \\
\text { crisis) }\end{array}$ & $\begin{array}{c}\text { Estimate of total } \\
\text { losses/costs } \\
\text { (percentage of GDP) }\end{array}$ \\
\hline Latin America & \\
Argentina (1980-82) & 55 \\
Chile (1981-83) & 41 \\
Venezuela (1994-95) & 18 \\
Mexico (1995) & $12-15^{\mathrm{a}}$ \\
& \\
Industrial countries & \\
Spain (1977-85) & 17 \\
Japan (1990s) & $10^{\mathrm{b}}$ \\
\hline a. accumulated loses to date. & \\
b. estimate of potential losses. & \\
Source: Goldstein (1997) &
\end{tabular}

How significant are the losses arising from perverse incentives in financial intermediaries? The US Savings and Loan crisis showed that they can spiral rapidly in the absence of prompt corrective action; and the ultimate resolution cost of the S \& L debacle was estimated at between two and three percent of GDP. The bill for clearing up after severe banking crisis (recapitalising and restructuring) is much greater. As can be seen from Table 7, resolution costs have run from ten percent to half of one year's GDP. (See also Lindgren et al. (1996).)

One key difference between the long-running debt crisis in Latin America in the 1980s and the spectacular crises in Asia in 1997, both of which involved lending by US and other western banks, is that the former produced the 1982 Volcker initiative and a general standstill on banking movements, whereas 1997 produced currency collapses in Asia. The main reason for this difference is the scale of western banks' involvement in 1982 (petro-dollar recycling, etc.) threatened their own solvency if they tried to withdraw funds, whereas in 1997 there was no such threat - at least until very late 1997 when Korea was faced with default and banks were persuaded to roll-over some of the short-term loans. Suggestions for forcing creditors to the negotiating table are discussed in the conclusions below. 


\section{Was it contagion?}

The Thai baht was forced off its peg in the summer of 1997 and it had lost a quarter of its value by October. This devaluation led to speculative pressure against neighbouring countries with exchange rate pegs against the dollar, especially Malaysia, Indonesia, and the Philippines. Even Hong Kong and Singapore came under pressure despite their strong current account and fiscal positions. This is commonly referred to as the effect of 'contagion'. What does that mean?

Table 8: Contemporaneous crisis: 4 causes

\begin{tabular}{|l|l|l|l|}
\hline Cause & Mechanism & Examples & Is it contagion? \\
\hline Common shock & $\begin{array}{l}\text { - High US interest rates } \\
\text { - Yen devaluation }\end{array}$ & $\begin{array}{l}\text { - Debt crises in 1980s } \\
\text { - East Asia 1996/7 }\end{array}$ & No \\
\hline $\begin{array}{l}\text { Spillover } \\
\text { externalities }\end{array}$ & $\begin{array}{l}\text { International } \\
\text { competitiveness }\end{array}$ & $\begin{array}{l}\text { ERM crises 1992/3 } \\
\text { East Asia 1997/8 }\end{array}$ & Maybe \\
\hline $\begin{array}{l}\text { Psychological } \\
\text { externalities }\end{array}$ & Changing expectations & $\begin{array}{l}\text { Sterling devaluation } \\
\text { 1992 (following hard on } \\
\text { heels of Lira) }\end{array}$ & Yes \\
\hline $\begin{array}{l}\text { Informational } \\
\text { externalities, } \\
\text { herding }\end{array}$ & Imperfect information & $\begin{array}{l}\text { Latin America 1982 ff } \\
\text { East Asia 1997 }\end{array}$ & Yes \\
\hline
\end{tabular}

To answer this question, Masson (1997) distinguishes various causes of contemporaneous crisis and these are shown in the first three rows of Table 8. First is where there exists a 'monsoonal effect' i.e., "a common cause, for instance, policies undertaken by industrial countries which have similar effects on emerging markets", p.2. The debt crisis in the early $1980 \mathrm{~s}$ is cited as an example where the common cause was a sharp increase in US interest rates. There is also surely abundant evidence of monsoonal effects in East Asia - the rise of US dollar against the yen, for example, and the challenge posed by the entry of China into world markets with some similar product lines and with a devalued currency. But we agree with Masson that this should not be referred to as contagion.

Second is where a crisis in one emerging market affects fundamentals in others, termed a 'spillover'. The example of the ERM crises illustrates: "the devaluation of several EMS currencies in 1992-93 made the parities of the remaining ones more fragile, since those countries' real effective exchange rates had appreciated", p.3. Note that such spillover effects are referred to as contagion by Gerlach and Smets (1994). 
In the third line of the table is what Masson himself defines as contagion, namely when a crisis in one country triggers the crisis elsewhere "for reasons unexplained by economic fundamentals, perhaps for psychological reasons or because lack of liquidity in one market leads financial intermediary to liquidate other emerging market assets", p.2. Thus he reserves the label for cases which essentially involve shifts of expectation in models of multiple equilibria ("contagion would only occur in a situation in which multiple equilibria were possible, and a crisis in one country would elsewhere trigger a shift from one of the equilibria to another", p.6). Obstfeld (1994) had pointed out that the market for international sovereign debt can have multiple equilibria $^{12}$; and in his ingenious paper, Masson extends the idea to explain the elements of contagion so clearly present in East Asia. He constructs a simple model for the purpose to see which countries were liable to suffer from this phenomenon.

In line four, we list separately the idea that contagion may be due to informational externalities rather than to purely psychological factors. Where hard information is difficult to come by, it may be tempting for agents to use the behaviour of others as a proxy. The result is herd behaviour, as analysed by Banerjee (1992), who uses it to explain why diners shun empty restaurants in favour of those that are already quite full. In their survey, Devenow and Welch (1996) conclude that such information externalities are the most general explanation of herding. (For the informational cascades and market crashes that may arise from pattern of learning see also In Ho Lee (1997).) Herding may well have occurred in East Asia where many investors had only limited information, partly because of a lack of effort on their side and partly also because of the lack of transparency in the markets themselves. In these circumstances, a bank run due to shaky fundamentals in one country could well be imitated elsewhere, as investors join the herd heading for the exit. This shift from good to bad equilibria induced by examples elsewhere is not unlike the multiple equilibria phenomenon described by Masson: but the mechanism at work here is an informational externality, possibly exacerbated by the monitoring rules governing investor behaviour (see Devenow and Welch (1996), pp.607-9): portfolio managers may be punished for continued exposure in regions with failing prospects.

\footnotetext{
${ }^{12}$ The reason is essentially that devaluation is a form of debt default: and expectations of the devaluation, by raising interest rates, actually make default more attractive. So, there often exist two
} 


\section{Crisis prevention and management}

What can be done to avert further financial crises or at least to mitigate their consequences? One step upon which most commentators are agreed is to improve the regulation of financial institutions in emerging countries, so as to insure greater transparency and proper monitoring of bank portfolios ${ }^{13}$, and taking prompt corrective action when danger threatens. Beyond that, commentators differ widely. We outline three contrasting views.

\section{a) "Go with the flow": the US Treasury view}

We begin with the 'liberal', or free market view of the US government as recently put by Larry Summers ${ }^{14}$, deputy secretary of the US treasury. "The case for capital account liberalisation", he argued, "is a case for allowing capital to seek the highest productivity investments", though he warned that "inflows in search of genuine economic opportunities are one thing. Inflows in search of government guarantees ....are quite another". In view of the acknowledged danger of liberalising capital flows when incentives are distorted, he concluded that "the pace of opening up should be matched by the pace of developing a sound domestic financial system".

What changes (if any) are needed at an international level? Summers acknowledges that "there will never be enough money in the world to respond as an official lender of last resort to all the crises that can appear... as capital flows increase"; but he dismisses proposals for "speed bumps or other forms of capital controls" as more likely to do harm than good. Three suggestions are made from improving the global financial system. The first two are familiar and uncontroversial - greater transparency and improved prudential standards; third is the proposal to "ensure that policymakers do not confront the choice between uncontrolled chaos and confusion, on the one hand, and large bailouts, on the other". Unfortunately, it is not made clear

possible equilibria - low interest rates with low default versus high interest rates with high default; and the switch from the former to the latter can be described as a crisis for the country in question.

${ }^{13}$ Canada and Britain have proposed a new surveillance structure for this purpose: this would combine the World Bank financial operations unit with staff from the IMF and be responsible both for general surveillance and for devising financial sector reform for countries in crises, (FT, April 15, 1998).

14 "Go with the flow", FT, March 11, 1998. 
how these can be achieved (though the reference to bankruptcy law implies some sort of workout procedure, see below).

\section{b) International monetary reform : A "first best" approach}

The appropriate counterpart to globalised capital markets would in principle be the globalisation of controls developed at the national level - mechanisms like deposit insurance and the lender of last resort. The former could well be delegated to national central banks; but not the latter. This poses the key question: can the IMF as currently constituted act as an effective international lender of last resort?

Even those in favour of substantial reform answer no. In Sachs's view, for example, IMF procedures are - and are bound to remain - too slow to stop bank runs in any case; and he is against enhancing their resources and discretion because, according to him, the IMF is already too powerful and too unaccountable ${ }^{15}$. Krugman too is sceptical: instead of "a sort of super-IMF with the huge resources needed to act as a full-fledged lender of last resort and with extensive direct regulatory powers over the banks of member countries," he reckons that "we will be lucky if the existing, farfrom-super IMF gets the modest funding increase it is seeking"16.

What about second best?

\section{c) International monetary reform : "Second best” approaches}

Noting that financial liberalisation preceded the dangerous build-up of shortterm foreign currency exposure in East Asia, Radelet and Sachs (1998b, p.40) conclude that ... "the rapid push towards fully open capital markets among the developing countries would seem to be misguided. There is certainly no strong empirical evidence that economic growth in middle-income developing countries depends on unfettered access to short-term capital flows from abroad... The policy goal ... should be to support long-term capital flows, especially foreign direct investment, and equity portfolio flows, but to limit short-term international flows mainly to the financing of short-term trade transactions".

Two mechanisms for doing so are discussed, first inflow controls (as in Chile) and second explicit supervisory limits. Though they concede the former are more

\footnotetext{
15 “IMF is a Power Unto Itself", FT, December 12, 1997.
} 
attractive on economic grounds, they argue for the latter in term of practical enforcement (administration and monitoring).

Since South Korean debt default was avoided by an involuntary roll-over on the part of western banks just before Christmas, Radelet and Sachs (1998b) make the case for generalised orderly work-out arrangements. ("The Korean negotiations demonstrated that such a mechanism could work in practice. Now, we suppose, we will have to discover whether it can work in theory and thereby pursued more systematically in future!”, p.43.) In other words, besides prudential limits on capital controls, they are hinting at another institutional innovation - equivalent of an International Bankruptcy Court. (See the discussion of a payment standstill for sovereign debt in Miller and Zhang, 1997.) Ironically enough, the most plausible venue would probably be the IMF itself!

\section{Looking Ahead}

How and when will these economies recovery from the crisis? The example of Mexico is encouraging as its growth rate dropped sharply but recovered quickly. Japan, however, provides a sombre warning, growth has not recovered from slowdown caused by the bursting asset bubbles of 1989. To the extent that the spectacular growth rates in Asia were a catch-up phenomenon, they cannot be extrapolated indefinitely, Young $(1994,1995)$ and Krugman (1994). So maybe it is too optimistic to expect a simple return of 'business as usual'. The enormous devaluation has made Asian goods more competitive in the world market. But there are three conditions for a resumption of healthy growth, which have yet to be fulfilled: first, the recapitalisation and restructuring of the financial systems in East Asia; second, the recovery of aggregate demand in Asia itself; and third, preventing any recurrence of the crisis.

In respect of the first two conditions, Japan plays a crucial role. But the economy there has been chronically weak for five years, with growing financial fragility and indecisive fiscal policy, and Japan is now in recession. People are increasing looking into China to take over as Asia's main engine of growth - even if the renminbi has to be devalued again. The third condition will require changes in the rules and practices of international finance, considered next.

\footnotetext{
16 "Start taking the Prozac", FT, April 9, 1998.
} 


\section{Conclusion}

There was evidence of flawed fundamentals in East Asia - overvaluation, overinvestment, and under-regulation, to name but three: but the countries concerned have learned bitter lessons and have every incentive to avoid any repetition. With rapidly liberalisation leading to feast followed by famine, it is evident that global capital markets have also misallocated resources. Actions now must be taken to resolve the burden of outstanding debts; and to change the international rules of the game to help prevent any recurrence. In particular, we propose the following:

a) Steps needed to resolve the current crisis

- For the Asian central banks to establish the magnitude of the potential losses resulting from implicit deposit insurance and to consider measures appropriate for financial resolution in such cases. It may be that the full payment of guarantees to foreign creditors should be made conditional on restructuring debt, i.e, long-term rollovers.

- For creditors and debtors (in Indonesia, for example) to get together to negotiate the write-down of debts that are beyond the capacity to pay. It has been suggested that to bring creditors to the negotiating table, debtors might consider a unilateral stay of payments and international financial institutions should continue to lend to them, subject to appropriate conditionality ${ }^{17}$.

\section{b) Steps to reform international monetary system}

i) establishing a surveillance mechanism of financial regulations and supervisory systems, jointly staffed by the IMF and the World Bank (which can also devise financial sector reforms for countries in crisis);

ii) devising a set of administratively practical, capital inflow controls and regulatory procedures along the lines of FDICIA (1991), to reduce financial vulnerability of the emerging market economies;

iii) not writing the requirement of capital account liberalisation into the Articles of the IMF until it is safe to do so; and

\footnotetext{
${ }^{17}$ The strategic case for a payments standstill is discussed in Miller and Zhang (1997); it appears that the Bank for International Settlements is advocating such a policy in this case (BIS, 1998, chapter 9).
} 
iv) instead, convening a Working Party of the G10 on 'Resolving Liquidity

Crises by Roll-overs and Workouts' to recommend changes in the Articles of the IMF needed to protect debtor countries trapped in liquidity crises ${ }^{18}$.

Without prompt action to resolve the current financial crisis, East Asia could be condemned to prolonged recession: without reform of the international monetary system, these crises will recur.

${ }^{18}$ This would be a follow-up of the Rey Report (1996) on the resolution of sovereign liquidity crises: but, given the gravity of the crises, it will hopefully have a much greater impact. 
APPENDIX 1 : Five Asian economies: Basic economic data

(In percent of GDP unless otherwise noted)

\section{INDONESIA}

Real sector

Real GDP growth ${ }^{2}$

Inflation $^{2,3}$

Domestic saving

Fixed capital formation

Public sector

General government balance

Public sector balance

Monetary sector

M2 growth (end of year) ${ }^{2}$

Domestic credit growth (end of year) ${ }^{2}$

Foreign liabilities of banks ${ }^{4}$

External sector

Current account balance

External debt service

\section{KOREA}

\section{Real sector}

Real GDP growth ${ }^{2}$

Inflation $^{2,3}$

Domestic saving

Fixed capital formation

Public sector

General government balance

Public sector balance

Monetary sector

M2 growth (end of year) ${ }^{2}$

Domestic credit growth (end of year) ${ }^{2}$

Foreign liabilities of banks ${ }^{4}$

External sector

Current account balance

External debt service

\section{MALAYSIA}

\section{Real sector}

Real GDP growth ${ }^{2}$

Inflation $^{2,3}$

Domestic saving

Fixed capital formation

Public sector

General government balance

Public sector balance

Monetary sector

M2 growth (end of year) ${ }^{2}$

Domestic credit growth (end of year) ${ }^{2}$

Foreign liabilities of banks ${ }^{4}$

$\begin{array}{rrrrrrrrrr}\mathbf{7 5 - 8 2} & \mathbf{8 3 - 8 9} & \mathbf{9 0} & \mathbf{9 1} & \mathbf{9 2} & \mathbf{9 3} & \mathbf{9 4} & \mathbf{9 5} & \mathbf{9 6} & \mathbf{9 7}^{1} \\ & & & & & & & & & \\ 6.2 & 5.5 & 9.0 & 8.9 & 7.2 & 7.3 & 7.5 & 8.2 & 8.0 & 5.0 \\ 15.0 & 8.1 & 7.8 & 9.4 & 7.5 & 9.7 & 8.5 & 9.4 & 7.9 & 8.3 \\ 19.3 & 23.2 & 27.9 & 28.7 & 27.3 & 31.4 & 29.2 & 29.0 & 28.8 & 27.3 \\ 19.8 & 24.3 & 28.3 & 27.0 & 25.8 & 26.3 & 27.6 & 28.4 & 28.1 & 26.5 \\ & & & & & & & & & \\ - & -1.3 & 1.3 & - & -1.2 & -0.7 & - & 0.8 & 1.4 & 2.0 \\ - & - & - & - & - & - & - & - & - & - \\ & & & & & & & & & \\ 29.3 & 27.0 & 44.6 & 17.5 & 19.8 & 20.2 & 20.0 & 27.2 & 27.2 & - \\ 42.1 & 48.3 & 58.3 & 18.9 & 14.1 & 21.0 & 22.9 & 21.7 & 22.7 & - \\ 2.2 & 4.2 & 11.0 & 8.6 & 10.3 & 20.9 & 10.9 & 9.6 & 8.5 & - \\ -1.2 & -3.5 & -2.8 & -3.4 & -2.2 & -1.5 & -1.7 & -3.3 & -3.3 & -2.9 \\ 3.5 & 6.8 & 8.3 & 8.4 & 8.7 & 8.4 & 8.6 & 8.5 & 9.0 & 10.5\end{array}$

$\begin{array}{rrrrrrrrrr}\mathbf{7 5 - 8 2} & \mathbf{8 3 - 8 9} & 90 & 91 & 92 & 93 & 94 & 95 & 96 & 97^{1} \\ 7.0 & 9.6 & 9.5 & 9.1 & 5.1 & 5.8 & 8.6 & 8.9 & 7.1 & 6.0 \\ 17.6 & 3.8 & 8.6 & 9.3 & 6.2 & 4.8 & 6.3 & 4.5 & 4.9 & 4.3 \\ 25.7 & 32.7 & 36.1 & 35.9 & 35.1 & 35.2 & 34.6 & 35.1 & 33.3 & 32.9 \\ 29.4 & 29.4 & 37.1 & 38.4 & 36.6 & 36.0 & 35.7 & 36.6 & 36.8 & 36.6 \\ & & & & & & & & & \\ -2.7 & -0.3 & -0.6 & -1.6 & -2.6 & -1.0 & -1.0 & - & - & - \\ - & - & - & - & - & - & - & - & - & - \\ & & & & & & & & & \\ 30.0 & 16.8 & 17.2 & 21.9 & 14.9 & 16.6 & 18.7 & 15.6 & 15.8 & - \\ 11.6 & 22.8 & 24.8 & 22.4 & 11.7 & 12.7 & 18.4 & 14.7 & 19.4 & - \\ 9.4 & 7.3 & 6.5 & 7.7 & 7.6 & 6.9 & 8.0 & 10.1 & 12.8 & - \\ -4.6 & 2.5 & -0.9 & -3.0 & -1.5 & 0.1 & -1.2 & -2.0 & -4.9 & -2.9 \\ - & - & - & - & - & - & - & - & - & -\end{array}$

$\begin{array}{rrrrrrrrrr}\mathbf{7 5 - 8 2} & \mathbf{8 3 - 8 9} & \mathbf{9 0} & \mathbf{9 1} & \mathbf{9 2} & \mathbf{9 3} & \mathbf{9 4} & \mathbf{9 5} & \mathbf{9 6} & \mathbf{9 7}^{1} \\ 7.1 & 5.4 & 9.6 & 8.6 & 7.8 & 8.3 & 9.2 & 9.5 & 8.6 & 7.0 \\ 5.3 & 2.0 & 2.8 & 2.6 & 4.7 & 3.5 & 3.7 & 3.4 & 3.5 & 3.7 \\ 21.6 & 29.4 & 29.1 & 28.4 & 31.3 & 33.0 & 32.7 & 33.5 & 36.7 & 37.0 \\ 29.4 & 28.5 & 32.4 & 36.4 & 36.0 & 38.3 & 40.1 & 43.0 & 42.2 & 42.7 \\ & & & & & & & & & \\ - & -4.0 & -2.2 & 0.1 & -3.5 & -2.6 & 2.5 & 3.8 & 4.2 & 1.6 \\ - & - & - & - & -3.5 & -2.6 & 2.5 & 3.2 & 1.6 & 1.8 \\ & & & & & & & & & \\ 20.2 & 9.2 & 10.6 & 16.9 & 29.2 & 26.6 & 12.7 & 20.0 & - & - \\ 5.3 & 19.9 & 18.0 & 18.5 & 16.6 & 12.3 & 14.8 & 29.5 & - & - \\ 6.3 & 6.7 & 7.3 & 9.0 & 13.0 & 19.5 & 8.8 & 6.5 & - & -\end{array}$




\section{External sector}

Current account balance

External debt service

\section{THAILAND}

\section{Real sector}

Real GDP growth ${ }^{2}$

Inflation 2,3

Domestic saving

Fixed capital formation

Public sector

General government balance

Public sector balance

Monetary sector

M2 growth (end of year) ${ }^{2}$

Domestic credit growth (end of year) ${ }^{2}$

Foreign liabilities of banks ${ }^{4}$

External sector

Current account balance

External debt service

\section{PHILIPPINES}

\section{Real sector}

Real GDP growth ${ }^{2}$

Inflation $^{2,3}$

Domestic saving

Fixed capital formation

Public sector

General government balance

Public sector balance

\section{Monetary sector}

M2 growth (end of year) ${ }^{2}$

Domestic credit growth (end of year) ${ }^{2}$

Foreign liabilities of banks ${ }^{4}$

External sector

Current account balance

External debt service

$\begin{array}{rrrrrrrrrr}-2.0 & -0.7 & -2.1 & -8.8 & -3.8 & -4.8 & -7.8 & -10.0 & -4.9 & -5.8 \\ 3.8 & 9.0 & 6.9 & 5.9 & 5.6 & 6.1 & 5.2 & 6.6 & 5.4 & 8.4\end{array}$

$\begin{array}{llllllllll}75-82 & 83-89 & 90 & 91 & 92 & 93 & 94 & 95 & 96 & 97^{1}\end{array}$

$\begin{array}{rrrrrrrrrr}7.0 & 8.1 & 11.6 & 8.1 & 8.2 & 8.5 & 8.9 & 8.7 & 6.4 & 0.6 \\ 9.0 & 3.1 & 6.0 & 5.7 & 4.1 & 3.4 & 5.1 & 5.8 & 5.9 & 6.0 \\ 19.6 & 25.4 & 32.6 & 35.2 & 34.3 & 34.9 & 34.9 & 34.3 & 33.1 & 31.8 \\ 23.6 & 27.7 & 40.2 & 41.6 & 39.2 & 39.4 & 39.9 & 41.8 & 40.8 & 35.8 \\ & & & & & & & & & \\ -5.8 & -3.0 & 4.4 & 4.2 & 2.6 & 2.1 & 2.0 & 2.6 & 1.6 & -0.4 \\ - & - & - & 4.0 & 1.6 & 0.9 & 1.8 & 2.5 & 2.2 & 1.9 \\ & & & & & & & & & \\ 19.3 & 18.8 & 26.7 & 19.8 & 15.6 & 18.4 & 12.9 & 17.0 & 12.6 & - \\ 15.6 & 19.8 & 26.8 & 15.5 & 18.0 & 22.7 & 28.9 & 23.1 & 14.0 & - \\ 5.8 & 6.3 & 6.4 & 6.0 & 6.9 & 11.7 & 20.3 & 24.3 & 23.3 & - \\ & & & & & & & & & \\ -5.6 & -3.2 & -8.3 & -7.7 & -5.6 & -5.0 & -5.6 & -8.0 & -7.9 & -3.9 \\ 3.8 & 5.8 & 3.8 & 4.0 & 4.3 & 4.4 & 4.8 & 5.0 & 5.4 & 7.1\end{array}$

$\begin{array}{rrrrrrrrrr}\mathbf{7 5 - 8 2} & \mathbf{8 3 - 8 9} & \mathbf{9 0} & \mathbf{9 1} & \mathbf{9 2} & \mathbf{9 3} & \mathbf{9 4} & \mathbf{9 5} & \mathbf{9 6} & \mathbf{9 7}^{1} \\ & & & & & & & & & \\ 5.6 & 1.1 & 3.0 & -0.6 & 0.3 & 2.1 & 4.4 & 4.8 & 5.7 & 4.3 \\ 11.0 & 15.4 & 12.7 & 18.7 & 8.9 & 7.6 & 9.0 & 8.1 & 8.4 & 5.2 \\ 19.9 & 18.1 & 18.7 & 18.0 & 19.5 & 18.4 & 19.4 & 17.8 & 19.7 & 21.0 \\ 26.7 & 20.7 & 24.0 & 20.0 & 20.9 & 23.8 & 23.6 & 22.2 & 23.2 & 25.1 \\ & & & & & & & & & \\ -2.0 & -2.8 & -3.5 & -2.1 & -1.2 & -1.6 & -1.6 & -1.4 & -0.4 & -0.9 \\ - & - & - & - & - & -2.0 & -0.6 & -0.1 & 0.1 & 0.3 \\ & & & & & & & & & \\ 20.5 & 21.4 & 22.5 & 17.3 & 13.9 & 27.1 & 24.4 & 24.2 & 23.2 & - \\ 6.2 & 21.5 & 30.7 & -2.6 & 17.6 & 131.2 & 19.0 & 31.3 & 40.3 & - \\ 16.0 & 12.9 & 14.9 & 11.5 & 12.9 & 10.9 & 12.9 & 13.9 & 21.9 & - \\ & & & & & & & & & \\ -6.5 & -0.3 & -6.1 & -2.3 & -1.6 & -5.5 & -4.6 & -4.4 & -4.7 & -4.5 \\ 5.5 & 8.5 & 8.1 & 9.0 & 7.2 & 7.8 & 7.2 & 6.5 & 7.3 & 6.0\end{array}$

Source: World Economic Outlook, IMF, December 1997.

${ }^{1}$ IMF estimate.

${ }^{2}$ Annual percent change.

${ }^{3}$ Consumer price index

${ }^{4}$ In percent of total liabilities of the banking system.

${ }^{5}$ Excludes prepayments and refinancing and includes staff estimates of short-term interest payments. 


\section{REFERENCE}

Allen, Franklin and Douglas Gale (1997), "Bubbles and Crises," paper presented at CEPR/ESRC/GEI Conference on The Origins and Management of Financial Crises, Cambridge, England, July.

Bagehot, Walter (1915), Lombard Street: A Description of the Money Market, London: Smith, Elder\&Co.

Banerjee, Abhijit (1992), “A Simple Model of Herd Behavior," Quarterly Journal of Economics, vol.107, pp.797-817.

Bernanke, Ben (1983), "Nonmonetary Effects of the Financial Crisis in the Propagation of the Great Depression," American Economic Review, vol.73, June, pp.257-276

Bhattacharya, Amar, Stijn Claessens, Swati Ghosh, Leonardo Hernandez, and Pedro Alba (1998), "Volatility and Contagion in a Financially-Integrated World: Lessons from East Asia's Recent Experience," paper presented at the CEPR/World Bank Conference on Financial Crises: Contagion and Market Volatility, London, May.

BIS (1998), Annual Report, Basle, Bank for International Settlements, June.

Bond, Timothy J and Marcus Miller (1998), "Financial Bailouts and Financial Crises," mimeo, International Monetary Fund, January.

Blanchard, Olivier (1979), "Speculative bubbles, Crashes and Rational expectations," Economic letters, p.387-9.

Calvo, Guillermo A. and Martin Goldstein (1996),"Crisis Prevention and Crisis Management after Mexico: What Role for the Offical Sector?" Center for international Economics Working Paper, no.24, University of Maryland.

Campbell, Donald E. (1995), Incentives: Motivation and the Economics of Information, Cambridge: Cambridge University Press.

Corsetti, Giancarlo, Paolo Pesenti, and Nouriel Roubini (1998), "What Caused the Asian Currency and Financial Crisis?" paper presented at the CEPR/World Bank Conference on Financial Crises: Contagion and Market Volatility, London, May.

Devenow, Andrea and Ive Welch (1996), "Rational Herding in Financial Economics," European Economic Review, no.40, pp.603-15.

Dewatripont, Mathias and Jean Tirole (1994), The Prudential Regulation of Banks, Cambridge, Mass : MIT Press.

Diamond, Douglas W. and Philip H. Dybvig (1983), "Bank Runs, Deposit Insurance, and Liquidity," Journal of Political Economy, vol.91, p.401-19. 
Dooley, Michael P. (1998), “A Model of Crises in Emerging Markets,” NBER Working Paper, no.6300.

Drees, Burkhard and Ceyla Pazarbasioglu (1998), "The Nordic Banking Crises: Pitfalls in Financial Liberalization," IMF Occasional Paper, no.161, International Monetary Fund, April.

Edison, Hali, Pongsak Luangaram and Marcus Miller (1998), "Asset Bubbles, Domino Effects, and 'Lifeboats': Elements of East Asian crisis," International Finance Discussion Papers, no.606, Board of Governors of the Federal Reserve System.

Friedman, Milton and Anna Schwatz (1963), A Monetary History of the United States 1867-1960, Princeton: Princeton University Press.

Garber, Peter (1990), "Famous First Bubbles,” Journal of Economic Perspectives, vol.4, pp.35-54.

Genotte, G., and Hayne Leland (1990), "Market Liquidity, Hedging and Crashes," American Economic Review, vol.80, p.999-1021.

Gerlach, Stefan, and Frank Smets (1994), "Contagious Speculative Attacks," CEPR Discussion Paper, no.1055.

Goldstein, Morris (1997), "The Case for an International Banking Standard," paper presented at CEPR/ESRC/GEI Conference on The Origins and Management of Financial Crises, Cambridge, England, July.

Grossman, Sandy (1987), “An Analysis of the Implications for Stock and Futures Price Volatility of Program Trading and Dynamic Hedging Strategies," NBER Working Paper, no.2357.

IIF (1998), Capital flow to Emerging market economies, Institute of International Finance, (29 January 1998).

IMF (1997), World Economic Outlook: Interim Assessment, Washington, DC, International Monetary Fund, December.

Kindleberger, Charles (1996), "Manias, Panics, and Crashes: A History of Financial Crises, Third Edition, New York: John Wiley and Sons.

Kiyotaki, Nobuhiro and John Moore (1997), "Credit Cycles," Journal of Political Economy, vol 105, April, pp.211-248.

Krugman, Paul (1979), “A Model of Balance-of-Payment Crises,” Journal of Money, Credit, and Banking, vol.11, p.311-25.

Krugman, Paul (1987), "Trigger Strategies and Price Dynamics in Equity and Foreign Exchange Markets," NBER Working paper, no.2459. 
Krugman, Paul (1990), The age of diminished expectations, Cambridge, Mass : MIT Press.

Krugman, Paul (1994), “The Myth of Asia's Miracle," Foreign Affairs, 73(6), November/December, p.62-78.

Krugman, Paul (1998), "What happened to Asia," mimeo, MIT, January.

Krugman, Paul and Marcus Miller (1993), "Why have a target zone?" CarnegieRochester Conference Series on Public Policy, no.38, pp.279-314.

Lee, In Ho (1997), Market Crashes and Information Avalanches, paper presented at CEPR/ESRC/GEI Conference on The Origins and Management of Financial Crises, Cambridge, England, July.

Lindgren, Carl, Gillian Garcia, and Mathew Saal (1996), "Bank Soundness and Macroeconomic Policy,” International Monetary Fund, Washington.

Luangaram, Pongsak (1997), "Credit constraints, Collateral, and Crisis: Thailand experiences and theoretical modelling," MSc Dissertation, University of Warwick, September.

Mazumdar, Sumon (1997), "Regulatory monitoring, Closure costs, and Bank moral hazard behavior," mimeo, August.

Masson, Pual (1997), "Monsoonal Effects, Spillovers and Contagion,” paper presented at CEPR/ESRC/GEI Conference on The Origins and Management of Financial Crises, Cambridge, England, July.

Miller, Marcus and Lei Zhang (1998), "Sovereign Liquidity Crises: The strategic case for a payments standstill," CEPR Discussion Paper no.1820, February.

Montgomery, John (1997), "The Indonesian Financial System: Its Contribution to Economic Performance, and Key Policy Issues," IMF Working Paper, WP/97/45, International Monetary Fund, April.

Obstfeld, Maurice (1994), "Logic of Currency Crises," Cahiers Economiques et Monetaires, 43, 189-213.

Obstfeld, Maurice (1996), "Models of Currency Crisis with Self-fulfilling Features," European Economic Review, vol.40, pp.1037-48

Obstfeld, Maurice and Kennett Rogoff (1997), Foundations of International Macroeconomics, Cambridge, Mass : MIT Press

Radelet, Steven and Jeffrey Sachs (1998a), "The Onset of the East Asian Financial Crisis," mimeo, Harvard Institute for International Development, March. 
Radelet, Steven and Jeffrey Sachs (1998b), “The East Asian Financial Crisis:

Diagnosis, Remedies, Prospects,"Brookings Papers on Economic Activity, forthcoming.

Rey, Jean-Jacques (1996), The Resolution of Soverign Liquidity Crises, Group of Ten, Washington, DC:IMF.

Sachs, Jeffrey (1995), "Do we need an international lender of last resort?" mimeo, Frank Graham lecture, Princeton University.

Salant, Stephen and Dale Henderson (1978), "Market Anticipation of Government Policy and the Price of Gold," Journal of Political Economy, vol.86, p.627-48.

Soros, George (1995), Soros on Soros: staying ahead of the curve, New York: John Wiley\&Son.

Young, Alwyn (1994), "Lessons from the East-Asian NICS - A contrarian view," European Economic Review, vol.38, pp.964-73.

Young, Alwyn (1995), "The Tyrancy of Numbers: Confronting the Statistical Realities of the East Asian Growth Experience," Quarterly Journal of Economics, vol.110, pp.641-80. 